\title{
Urban form and travel behavior: Experience from a Nordic context
}

\section{Petter Næss}

\author{
Aalborg University
}

\begin{abstract}
This article surveys the results of research carried out in the Nordic countries on the influence of various aspects of urban form and settlement patterns on travel behavior and discusses these results in the view of studies carried out in other European, American, Australian, and Asian countries. There is overwhelming evidence that urban spatial structures matter to travel behavior. However, whereas much of the research in America and parts of Europe has focused on the influences of local neighborhood characteristics on travel, the Nordic research shows effects on travel behavior mainly from urban form characteristics at a higher geographical scale: the overall population density within continuous urban areas and the locations of residences and workplaces relative to the city-level or metropolitan center structure.
\end{abstract}

\section{Introduction}

This article surveys the results of research carried out in the Nordic countries on the influence of various aspects of urban form and settlement patterns on travel behavior and discusses these results in the view of studies carried out in a wider international context. The focus of the article is on the influence of urban land use (the geographical distribution and density of the building stock and the urban functions therein) and settlement patterns on transportation variables. The paper does not directly address the impacts of transport infrastructure such as road provision, public transport service level, and the availability of parking.

Depending on the policy context, different studies of relationships between land use and travel have focused on different transport and travel parameters such as trip frequency, trip distances, choices of travel modes, or overall vehicle kilometers traveled. Reflecting a perspective of environmentally sustainable mobility and greenhouse gas mitigation, this article focuses on the transport variables of overall traveling distances, traveling distances by mode, modal shares, and energy consumption. Such an environmental perspective in studies of relationships between land use and travel has been prominent for decades in the Nordic countries, which are often referred to as forerunners in terms of sustainable urban development. For example, in 1993 the Norwegian government introduced national policy provisions on coordinated land use and transport planning, requiring municipalities to plan their land use in such a way that the amount of transport, as well as the need for travel by car, could be minimized. In Denmark, national policies that put pressure on municipalities in the Copenhagen metropolitan area to locate new office and residential develop- ment close to urban rail stations have been in place since the late 1980s. The Nordic countries are characterized by a relatively high acceptance among the population of land use regulations, with planning legislation enabling the municipalities to prohibit urban development in areas where it is not considered desirable. There are also national and regional policies and plans that can, to some extent, influence the pattern of development in regions where the functional city covers more than one municipality. This may be one of the explanations why Nordic studies have focused to a higher extent on urban form characteristics at a city-wide or metropolitan scale ${ }^{1}$, rather than the neighborhood-scale focus typical of many American studies (see Boarnet \& Crane 2001). Partly due to land use policies aiming to reduce car dependence and the need for travel, urban sprawl has been reduced substantially, and in cities such as Copenhagen and, in particular, Oslo, population densities have increased during the latest decades (Næss, Næss \& Strand 2011; Næss et al. 2011).

\footnotetext{
1 In this paper, the term "city" includes urban settlements with a population size above the level of villages and independent of municipal borders or other administrative territorial demarcations. We thus do not distinguish between cities and towns, although the latter concept is also sometimes used. The term metropolitan area refers to larger urban regions socio-economically linked to the urban core by commuting as well as trips for shopping and leisure purposes. In a Nordic context, the term is used about the urban regions of Copenhagen, Stockholm, Helsinki, and Oslo, ranging from 1.2 million to 1.8 million inhabitants, and with a share between two-thirds and threefourths of the metropolitan populations living within the continuous urban area of the core city. The metropolitan areas include rural inhabitants, but they make up only a small proportion (e.g., 4 percent and 9 percent in the metropolitan areas of Copenhagen and Oslo). We use the terms "suburb" and "suburban" in a way that includes outer districts of the core city as well as separate settlements located outside the core city but within the metropolitan area.
}

a petter@plan.aau.dk 
Most of the studies reviewed are confined to travel, thus omitting freight. Some of the studies of energy consumption still include energy used for transportation of both persons and goods.

Several authors have summarized the main findings from individual studies of associations between urban form characteristics and travel behavior (Stead \& Marshall 2001; Cao et al. 2009; Ewing \& Cervero 2001 and 2010; Lefevre 2010). In some cases, such summarizing has been carried out as socalled meta-analyses, where the quantified effects of urban form variables on travel behavior variables in different studies have been used as input data for statistical analyses of the average strengths of these relationships across the individual studies (Ewing \& Cervero 2010). While illustrating that the overwhelming majority of studies show an influence of urban form on travel, compared to the few studies where no such influence has been found, such meta-analyses still have clear limitations. For one thing, they do not distinguish between methodologically strong and weak studies-e.g., in terms of data quality and the inclusion of relevant factors of influence (Zegras 2010). Furthermore, it is often not clear whether the effect of a particular urban form characteristic (e.g., the design of the local street network) in a study included in the meta-analysis has been controlled for other relevant urban form variables (e.g., the distance from the dwelling to downtown). There is also an overall American dominance in most existing surveys of the status of knowledge. This in itself justifies the purpose of the present article: to provide an overview of the main urban form characteristics found to influence travel behavior within a Nordic context, based on a critical assessment of the methods, data sources, and theoretical underpinnings of the research results. Similarities and differences between the findings of the Nordic studies and research carried out in other parts of the world will be discussed, and possible explanations of any divergences will be suggested.

\section{Theoretical reasons why land use must be expected to influence travel}

Theories of transport geography and transport economy consider the travel between different destinations to be influenced on the one hand by the reasons people may have for going to a place, and on the other hand by the costs and inconvenience involved when traveling to this location (Jones 1978). Urban form affects the price of travel, which in turn influences consumption of travel (Boarnet \& Crane 2001). By determining the distances between locations where different activities may be carried out, and by facilitating different modes of travel, ur- ban form characteristics make up a set of conditions facilitating some kinds of travel behavior while discouraging other types of travel behavior. Needless to say, the causes of travel behavior also include personal characteristics such as age, gender, affluence level, and employment as well as norms, values, lifestyles, acquaintances, and social obligations. The emerging transportation pattern (trip frequencies, choices of destinations, modes of traveling, and trip routes) is a result of people's resources, needs, and wishes, modified by the constraints and opportunities of urban form characteristics as well as other structural conditions of society.

For the city as a whole, high population density implies shorter average distances between residences, workplaces, and service facilities than in a city with a dispersed pattern of development. The gain in the form of travelling distances includes shorter trips from home to work and service facilities, better opportunities for linking different trip purposes, and shorter trips when visiting friends and relatives living in the same city. Furthermore, a high population density facilitates more frequent public transport departures and shorter walking distances to bus stops and metro stations. Because distances between activities are shorter in dense cities, a higher proportion of the destinations will also be within walking or cycling distances. Furthermore, in dense urban areas, streets are usually narrower, and there is less space available for parking than in less densely developed areas.

The distance-reducing effect of high density is greater in large settlements than in small. In small towns and villages, the distance across the city is usually moderate even if the population density is low. For small settlements, the distance to larger settlements where job opportunities, service, and leisure facilities are concentrated is usually more important to travel behavior than the density within the small local settlement. Moreover, smaller settlements tend to be less dense than bigger settlements, reflecting land value gradients as well as cultural traditions. The effect of settlement size in itself may be moderate, as the effect of short cross-town distances in small settlements is counterweighed by their lower densities and higher dependence on job opportunities and other facilities outside the local settlement.

In spite of decentralizing trends, most European cities still have a higher concentration of workplaces, retail, public agencies, cultural events, and leisure facilities in the historical urban center and its immediate surroundings than in the peripheral parts of the urban area (Newman \& Kenworthy, 1999: 94-95; Næss 2006, among other authors). The inner and central parts of the metropolitan area include the largest supply of work opportunities, the broadest range of commodities in the shops, and the highest diversity of service facilities. For residents of 
the inner and central parts of the city, the distances to this concentration of facilities will be short. Inner-city residents could thus be expected on average to make shorter daily trips than their outer-area counterparts, with a higher proportion of destinations within acceptable walking or biking distance. Localscale urban design principles, such as street pattern, availability of sidewalks and bike paths, etc., and aesthetic neighborhood qualities, can influence the attractiveness of nonmotorized travel modes and can for some travel purposes also affect trip destinations. Such characteristics have been at the core of the interest of American studies of the influence of the built environment on travel behavior.

A central location of employment opportunities could also be expected to contribute to lower energy consumption for transport. The accessibility by public transport is usually highest in the central parts of the city. In addition, congestion and scarcity of parking space in downtown areas may cause a number of potential car commuters to leave their car in the garage at home. Distinct from this, suburban jobs are often poorly accessible by transit, while access by car is easy with less congested roads and usually ample parking.

As can be seen, there are good theoretical reasons to assume urban transport to be influenced by urban form characteristics. Doubts are still sometimes raised about the existence of any influences of urban form on travel behavior (Breheny 1994; Gordon \& Richardson 1997; Williams et al. 2000; Headicar 2003; Bruegmann 2005). However, as will be shown in the following sections, the evidence that urban spatial structures matter to travel behavior is quite overwhelming. There may still be disagreement as to which urban form characteristics are the most influential ones.

Counteracting mechanisms may also be operating. For example, the shorter distances between functions facilitated by dense cities or inner-city residential locations could be utilized by opting for a wider range of workplaces, shops, and residences and by increasing the frequency of trips, rather than reducing the amount of travel (Crane,1996). Similarly, the money and time saved by living close to daily destinations could be spent on making longer leisure trips, perhaps by airplane (Vilhelmson 1990). In the literature on the effects of environmental policy measures, such counteracting mechanisms are referred to as rebound effects (Nørgaard 2008; see also Holden 2007 and Næss 2006b). It is important to be aware that the existence of such (partly) compensatory mechanisms does not reduce the causal influence of urban form on travel. Urban travel is influenced by a multitude of causes, some of which may reinforce each other and others that may counteract each other. The causal influences of urban form on individuals' travel behavior thus exist independently of whether, for example, any tenden- cy of more trips by airplane among people living close to daily destinations is counteracted by heavier $\mathrm{CO}_{2}$ taxes on flights (see Bhaskar 1998; Nrss 2004). Causality is not the same as correlation and need not manifest itself as "event regularities." At a city scale, though, the causal influence of urban form characteristics on aggregate travel behavioral patterns requires the causal mechanisms by which urban form influences travel behavior at the individual level to be on average strong enough to outweigh any counteracting mechanisms. The emergence of city-level causal relationships between urban form and travel thus presupposes a certain degree of event regularities in the form of more or less strong correlations between urban form characteristics and the travel behavior of the city's inhabitants (Næss 2004).

\section{Methods and sources of knowledge}

Urban planners and urban geographers have for a long time presupposed that urban land use influences transport and travel behavior. In particular, the oil embargos in 1973/74 and $1979 / 80$ triggered considerable interest in research into relationships between urban form and transportation (Real Estate Research Corporation 1974; Needham 1977; Burchell \& Listokin 1982; Owens 1986). Some of these studies were purely theoretical analyses. Several other early studies were based on model simulations of hypothetical land use scenarios. The latter illustrated and synthesized already existing assumptions about transportation consequences of alternative urban structures, but could of course not be used to investigate whether the model's assumptions about the influences between its variables were correct. The first empirical studies into the land use-transport relationship (Keyes 1976; Newman \& Kenworthy 1989, among others) were comparisons of transportation fuel usage at an aggregate level (typically between cities or metropolitan areas). Later on, an increasing number of studies were carried out at a disaggregate level, with households or individuals as units of analysis. At first, few of these studies took into account factors of influence other than the urban structural variables the studies were focused on. Gradually, several empirical investigations have been carried out, incorporating urban form variables as well as demographic and socioeconomic factors in the analyses. Although most studies carried out during the latest couple of decades have attempted to control for demographic and socioeconomic variables, a number of authors still hold that the possibility that people base their choice of residence partly on preference for a particular travel mode precludes any firm conclusions about the influence of residential location on travel (Kitamura et al. 1997; Boarnet 
\& Crane 2001; Krizek 2003; Schwanen \& Mokhtarian 2004; Schreiner \& Holz-Rau 2007; Cao, Mokhtarian \& Handy 2009). A growing number of recent studies have therefore explicitly addressed this so-called "self-selection problem," often by including variables measuring residential preferences and/or transport attitudes, but also by using other methodologies such as instrumental variables, joint discrete choice models, structural equations models, and longitudinal designs. However, statistical analyses, even with inclusion of the relevant socioeconomic and attitudinal variables, cannot themselves establish that causality exists between urban form and travel. In a few studies, the traditional quantitative travel survey approach has therefore been combined with qualitative interviews in order to identify the more detailed mechanisms through which urban structure affects travel behavior.

\section{$4 \quad$ The Nordic studies reviewed}

In the following sections, a total of 30 Nordic studies on the influence of urban form on travel carried out during the period since 1982 will be reviewed. These studies include, as far as the author is aware of, all published empirical research on the topic carried out in a Nordic context during the last three decades ${ }^{2}$. There are considerable differences among the five Nordic countries in terms of their research activity within this field. Of the 30 studies, 15 have investigated Norwegian cases, 9 have studied Danish cases, 4 have focused on Swedish contexts, 1 has investigated Finnish settlements, and 1 study has compared cities in 4 Nordic countries (Norway, Denmark, Sweden, and Iceland). Table 1 shows, in chronological order, publication reference(s), study area, geographical scale, investigated urban form variables, and main methodological approach of each of these studies. First, evidence of causality from qualitative research will be presented (section 5). Following that, results from research investigating the influence of different aspects of urban form will be reviewed, starting with the neighborhood scale and moving upward in scale via the city/metropolitan level to a regional scale. In section 6, neighborhood-scale density will thus be addressed, followed by local street pattern (section 7), residential location at a city/metropolitan scale (section 8), location of workplaces and retail at a city/metropolitan scale (section 9), population density at a city scale (section 10), and the issue of centralization vs. decentralization at a regional scale (section 11). To identify the most credible knowledge claims in situations where there are divergent conclusions, emphasis will

2 Because of language barriers, the author's knowledge of Finnish studies may not be complete. be laid on criteria such as theoretical plausibility; consistency with qualitative research on rationales for transport behavior; control for relevant non-urban-structural variables as well as for other urban structural variables than the one focused on; non-inclusion of irrelevant control variables; and consideration of whether the self-selection issue has been dealt with.

\section{$5 \quad$ Causality and transport rationales}

In order to substantiate that residential location is a (contributory) cause of differences in travel behavior, the basic mechanisms by which residential location influences travel behavior must be identified. Examples showing the rationales on which people base their frequency of participation in out-of-home activities, the locations of these activities, the modes of travel used to reach these locations, and the routes followed make up important links in the mechanisms by which urban structures influence travel behavior. Transport rationales are understood here as the backgrounds, motivations, and justifications that agents draw on when they make transport-relevant decisions about their participation in activities, location of these activities, modes of transportation, and the routes followed (Næss \& Jensen 2005, 165). The concept, which includes instrumental, safety-based, comfort-based, and aesthetic as well as affective dimensions, has some overlap with the notion of "mobility view," a term coined by Beckmann (2001). Combined with the spatial configuration of residences, employment, and other facilities in a city or metropolitan area, the transport rationales produce some characteristic relationships between residential location and travel found in a number of different urban contexts.

Internationally, relatively few studies have included qualitative interviews in order to identify such rationales, reflecting a general dominance of quantitative research within the field of land use and transport studies. However, among the few qualitative investigations of transport rationales, a high proportion has been carried out in a Nordic context (Røe 2001; Tillberg 2001; Nielsen 2002; Næss \& Jensen 2002, 2004, and 2005; Næss 2005, 2006a). These studies have been carried out in different urban contexts: the metropolitan areas of Oslo in Norway and Copenhagen in Denmark, the medium-sized towns of Aalborg (Denmark) and Gävle (Sweden), and the small town of Frederikshavn in Denmark. Nevertheless, the rationales identified in the different urban regions are highly consistent.

Based on interviews with 15 individuals living in 3 different locations in Oslo (the inner city, a suburb along an urban 
Table 1: Overview of the 30 Nordic studies included in the review.

\begin{tabular}{|c|c|c|c|c|}
\hline Reference & Study area & Geographical scale ${ }^{3}$ & $\begin{array}{l}\text { Urban form vari- } \\
\text { ables investigated }\end{array}$ & Main methodological approach \\
\hline Larsen (1982) & $\begin{array}{l}\text { Danish urban } \\
\text { settlements }\end{array}$ & Different settlement categories & $\begin{array}{l}\text { Regional settlement } \\
\text { structure }\end{array}$ & $\begin{array}{l}\text { Multivariate modeling based on empirical input } \\
\text { from national travel surveys }\end{array}$ \\
\hline $\begin{array}{l}\text { Monsen } \\
(1983)\end{array}$ & $\begin{array}{l}\text { Greater Oslo, } \\
\text { Norway }\end{array}$ & $\begin{array}{l}\text { Workplace areas within the continu- } \\
\text { ous urban area (pop. } 0.9 \text { mill.) }\end{array}$ & Workplace location & $\begin{array}{l}\text { Project-specific travel survey among employees of } \\
\text { four companies before and after relocation }\end{array}$ \\
\hline $\begin{array}{l}\text { Synnes } \\
(1990)\end{array}$ & $\begin{array}{l}\text { Trondheim, } \\
\text { Norway }\end{array}$ & $\begin{array}{l}\text { Residential zones within the continu- } \\
\text { ous urban area (pop. 160,000) }\end{array}$ & Residential location & $\begin{array}{l}\text { Comparison of data from local travel survey in- } \\
\text { cluding approx. } 300 \text { individuals living in } 15 \\
\text { different residential zones }\end{array}$ \\
\hline $\begin{array}{l}\text { Hanssen } \\
(1993)\end{array}$ & $\begin{array}{l}\text { Greater Oslo, } \\
\text { Norway }\end{array}$ & $\begin{array}{l}\text { Workplace areas within the continu- } \\
\text { ous urban area (pop. } 0.9 \text { mill.) }\end{array}$ & Workplace location & $\begin{array}{l}\text { Project-specific travel survey among employees of } \\
\text { different branches of a company before and after } \\
\text { moving to new, common site }\end{array}$ \\
\hline Næss (1993) & $\begin{array}{l}\text { The } 97 \text { largest cit- } \\
\text { ies in Sweden and } \\
15 \text { Swedish com- } \\
\text { muting regions }\end{array}$ & $\begin{array}{l}\text { Continuous urban areas (pop. 10,000 } \\
-1.4 \text { mill.), and commuting regions } \\
\text { (defined as areas within } 35 \mathrm{~km} \text { direct } \\
\text { distance from the region center) }\end{array}$ & $\begin{array}{l}\text { City-level density, } \\
\text { regional settlement } \\
\text { structure }\end{array}$ & $\begin{array}{l}\text { Multivariate analysis based on fuel sales statistics at } \\
\text { municipal level and electricity consumption for rail } \\
\text { transport }\end{array}$ \\
\hline $\begin{array}{l}\text { Martamo } \\
(1995)\end{array}$ & $\begin{array}{l}\text { All Finnish } \\
\text { municipalities }\end{array}$ & Municipalities & $\begin{array}{l}\text { Residential location, } \\
\text { workplace location, } \\
\text { regional settlement } \\
\text { structure }\end{array}$ & $\begin{array}{l}\text { National census statistics on commuting trip } \\
\text { lengths among working residents of each munici- } \\
\text { pality as well as employees within each } 500 \text { by } 500 \\
\text { m square of the entire area of Finland }\end{array}$ \\
\hline $\begin{array}{l}\text { Næss, Røe \& } \\
\text { Larsen (1995) }\end{array}$ & $\begin{array}{l}\text { Greater Oslo, } \\
\text { Norway }\end{array}$ & $\begin{array}{l}\text { Residential areas within the continu- } \\
\text { ous urban area (pop. } 0.9 \text { mill.) }\end{array}$ & $\begin{array}{l}\text { Residential location, } \\
\text { neighborhood density }\end{array}$ & $\begin{array}{l}\text { Multivariate analysis of data from project-specific } \\
\text { investigation among } 321 \text { households in } 30 \text { residen- } \\
\text { tial areas }\end{array}$ \\
\hline $\begin{array}{l}\text { Svensson } \\
(1998)\end{array}$ & $\begin{array}{l}\text { Linköping, } \\
\text { Sweden }\end{array}$ & $\begin{array}{l}\text { Out-of-town shopping malls and } \\
\text { stores within the continuous urban } \\
\text { area (pop. 97,000) }\end{array}$ & Location of shopping & $\begin{array}{l}\text { Project-specific travel surveys among individuals } \\
(\mathrm{N}=\text { approx. } 2000) \text { before and after the establish- } \\
\text { ment of } 3 \text { out-of-town shopping malls }\end{array}$ \\
\hline $\begin{array}{l}\text { Møller \& } \\
\text { Næss (2000) }\end{array}$ & Aalborg, Denmark & $\begin{array}{l}\text { Workplace areas within the continu- } \\
\text { ous urban area (pop. 120,000) }\end{array}$ & Workplace location & $\begin{array}{l}\text { Analysis of project-specific travel survey among } \\
\text { employees of } 4 \text { schools/public agencies }\end{array}$ \\
\hline $\begin{array}{l}\text { Hjorthol } \\
(2000 a)\end{array}$ & Oslo, Norway & $\begin{array}{l}\text { Different counties within Oslo metro- } \\
\text { politan area (pop. } 1.2 \text { mill.) }\end{array}$ & Residential location & $\begin{array}{l}\text { Multivariate analysis of data subset from national } \\
\text { travel survey }(\mathrm{N}=791)\end{array}$ \\
\hline $\begin{array}{l}\text { Hjorthol } \\
\text { (2000b) }\end{array}$ & Oslo, Norway & $\begin{array}{l}\text { A central area, a suburban area, and a } \\
\text { railway town in the Oslo region } \\
\text { (pop. } 1.2 \text { mill.) }\end{array}$ & Residential location & $\begin{array}{l}\text { Multivariate analysis of data subset from national } \\
\text { travel survey }(\mathrm{N}=1900) \text {, combined with focus } \\
\text { group interviews in } 3 \text { areas }\end{array}$ \\
\hline $\begin{array}{l}\text { Hansen } \\
\& \text { Masud } \\
(2001)\end{array}$ & $\begin{array}{l}\text { Randers, } \\
\text { Denmark }\end{array}$ & $\begin{array}{l}\text { Residential areas in the city and sur- } \\
\text { rounding settlements (pop. 60,000) }\end{array}$ & Residential location & $\begin{array}{l}\text { Qualitative interviews and travel registration } \\
\text { among } 12 \text { households in } 4 \text { residential areas }\end{array}$ \\
\hline Røe (2001) & Oslo, Norway & $\begin{array}{l}\text { Residential areas within the core } \\
\text { municipality (Oslo) (pop. } 0.6 \text { mill.) }\end{array}$ & Residential location & $\begin{array}{l}\text { Qualitative interviews of } 15 \text { individuals living in } 3 \\
\text { areas, and project-specific travel survey among } 400 \\
\text { households in } 30 \text { residential areas }\end{array}$ \\
\hline
\end{tabular}

3 Population figures refer to the contemporary (2010 or 2011) number of inhabitants, which may differ from the population size at the year of investigation. 


\begin{tabular}{|c|c|c|}
\hline $\begin{array}{l}\text { Hartoft- } \\
\text { Nielsen } \\
\text { (2001a) }\end{array}$ & $\begin{array}{l}\text { Copenhagen, } \\
\text { Aarhus, and four } \\
\text { smaller Danish } \\
\text { cities }\end{array}$ & $\begin{array}{l}\text { Residential areas within the metro- } \\
\text { politan area/city and surrounding } \\
\text { settlements }\end{array}$ \\
\hline $\begin{array}{l}\text { Hartoft- } \\
\text { Nielsen } \\
\text { (2001b) }\end{array}$ & $\begin{array}{l}\text { Greater Copen- } \\
\text { hagen and the } \\
\text { cities of Aarhus, } \\
\text { Odense, and } \\
\text { Aalborg, Denmark }\end{array}$ & $\begin{array}{l}\text { Workplace areas within the con- } \\
\text { tinuous urban areas (pop. } 1.2 \text { mill., } \\
240,000 ; 160,000 \text { and 120,000, } \\
\text { respectively) }\end{array}$ \\
\hline $\begin{array}{l}\text { Strømmen } \\
(2001)\end{array}$ & $\begin{array}{l}\text { Trondheim, } \\
\text { Norway }\end{array}$ & $\begin{array}{l}\text { Workplace areas within the continu- } \\
\text { ous urban area (pop. 160,000) }\end{array}$ \\
\hline $\begin{array}{l}\text { Tillberg } \\
\text { (2001) }\end{array}$ & Gävle, Sweden & $\begin{array}{l}\text { Residential areas in the city and sur- } \\
\text { rounding settlements (pop. 95,000) }\end{array}$ \\
\hline $\begin{array}{l}\text { Nielsen } \\
(2002)\end{array}$ & Aalborg, Denmark & $\begin{array}{l}\text { Residential areas within the city } \\
\text { and surrounding settlements (pop. } \\
160,000 \text { ) }\end{array}$ \\
\hline $\begin{array}{l}\text { Næss \& } \\
\text { Johannsen } \\
(2003)\end{array}$ & $\begin{array}{l}\text { Three previous } \\
\text { Danish counties }\end{array}$ & $\begin{array}{l}\text { Intra-county and inter-county com- } \\
\text { parisons }\end{array}$ \\
\hline $\begin{array}{l}\text { Næss \& } \\
\text { Jensen }(2002 \text {, } \\
2004)\end{array}$ & $\begin{array}{l}\text { Frederikshavn, } \\
\text { Denmark }\end{array}$ & $\begin{array}{l}\text { Residential areas within the city and } \\
\text { surrounding settlements (pop. } 35,000\end{array}$ \\
\hline $\begin{array}{l}\text { Engebretsen } \\
(2005)\end{array}$ & $\begin{array}{l}\text { The Norwegian } \\
\text { cities of Greater } \\
\text { Oslo, Bergen, and } \\
\text { Trondheim, and } 4 \\
\text { smaller cities }\end{array}$ & $\begin{array}{l}\text { Census units within the continuous } \\
\text { urban areas (pop. } 0.9 \text { mill., } 220,000 \\
160,000 \text {, and } 20,000-40,000, \\
\text { respectively) }\end{array}$ \\
\hline
\end{tabular}

Holden \& $\quad$ Oslo, Norway

Norland

(2004)

Næss (2005,

2006a,

2006b, 2009

and 2011)

$\begin{array}{ll}\begin{array}{l}\text { Tennøy \& } \\ \text { Lowry (2008) }\end{array} & \text { Oslo, Norway } \\ \begin{array}{l}\text { Westford } \\ (2010)\end{array} & \begin{array}{l}\text { Stockholm, } \\ \text { Sweden }\end{array} \\ \begin{array}{ll}\text { Engebretsen, } \\ \text { Hanssen \& } \\ \text { Strand (2010) }\end{array} & \begin{array}{l}\text { Norwegian cities } \\ \text { within different } \\ \text { size categories (ag- } \\ \text { gregate data) }\end{array}\end{array}$

Residential areas within the continuous urban area (pop. 0.9 mill.) tan area (pop. 1.8 mill.)

metropolitan area,

Denmark

Workplace areas within the core municipality (Oslo) (pop. 0.6 mill.) with different street patterns

Residents living at different locations within cities and surrounding areas
Residential location

Workplace location

Workplace location

Residential location

Residential location

Regional settlement structure

Residential location, neighborhood density

Residential location

Residential areas within the metropoli-

Neighborhoods in the suburb of Täby
Residential location, neighborhood density

Residential location, neighborhood density, street pattern, regional settlement structure

Workplace location

Street pattern

Residential location, location of shopping, neighborhood density
Project-specific travel surveys among residents of new housing areas in each city. Bivariate analyses, but separate analyses for high- and low-income respondents

Comparison of data from project-specific travel survey among employees of office workplaces differently located

Comparison of data from project-specific travel survey among employees of 9 differently located workplaces

Qualitative interviews and project-specific travel survey among 83 families with children in 3 residential areas

Multivariate analysis of project-specific travel survey among 1200 individuals in 23 residential areas, and qualitative interviews of 16 households living at different locations.

Multivariate analysis of project-specific travel survey among 969 individuals living at different locations in the three countries

Multivariate analysis of project-specific travel survey among 628 individuals in 11 residential areas, and qualitative interviews of 6 households living at different locations

Analysis of data from national and regional travel surveys of a total of 55,000 respondents living in different census units.

Multivariate analysis of project-specific travel survey among 941 individuals in 8 residential areas

Qualitative interviews of 17 households living at different locations, multivariate analysis of projectspecific travel survey among 1932 individuals in 29 residential areas, and analysis of travel diary investigation among 273 of those

Project-specific travel survey among employees of different companies before and after moving to new, common site

Multivariate analysis of data from project-specific travel survey among 449 residents in 4 neighborhoods about their children's trips to school

Analysis of data from national and regional travel surveys of shopping trips among 17,500 respondents living at different locations 
rail line, and a low-density area with poor public transport access), Røe (2001) characterizes the mobility lifestyle of most of his interviewees as "late-modern" and spatially flexible. Typical for this mobility lifestyle is that proximity is of minor importance when choosing where to live, work, and carry out leisure activities. The social networks are also spread over a large area, sometimes including exurban areas. Some of his interviewees have few mobility resources, so their mobility lifestyle (characterized by Røe as "high-modern") is therefore less flexible, based to a high extent on public transportation. However, for both mobility lifestyle groups, residential location has a bearing on travel behavior. For the highly flexible individuals, residential location in the inner city, with its many facilities in near proximity of the dwelling, allows choices among the many services in the vicinity of the dwelling as well as elsewhere in the urban region. In contrast, people belonging to the same mobility lifestyle group and living at the outskirts of the city need to travel long distances in order to meet their preferences. For inner-city residents with less flexible mobility lifestyles, availability of a wide range and number of facilities within a relatively short distance from the dwelling allows many opportunities for choice despite these interviewees' relatively confined geographical radius of action. Members of the low-mobility lifestyle group living in the suburbs are, however, experiencing several spatial constraints and a low degree of freedom of choice, especially if the area is poorly served by public transportation. (Røe 2001, 221.)

In her study of activity participation and travel behavior among families with children in the Swedish city of Gävle and its surroundings, Tillberg (2001) found that chauffeuring to children's organized leisure activities often dominated the household's time schedule after work. The rural children were engaged in urban-based activities to the same extent as the children living close to the city center. Although the rural parents had often been motivated to move to a peripheral settlement by assuming favorable conditions for children's play in such areas, rural children often spent less time than inner-city children in their home milieu because of their extensive and timeconsuming travel to organized leisure activities.

Based on interviews among households in Aalborg, Nielsen (2002) finds that the location of jobs and leisure activities is usually chosen within the entire urban area (as distinct from within the local neighborhood). The same is also partly true for social contacts, although people who have recently moved to the city (and thus have not yet developed a wide social network) and parents of children may to a higher extent maintain social contacts within the local neighborhood. Grocery shopping is an example of an activity more often taking place locally (if possible), yet many people may prefer to shop in a larger store on the way home from work. For the activities for which locations are chosen within a wider area, mean trip distances among the residents of a neighborhood depend on where the chosen facilities are located on average. Because of the concentration of jobs, stores, and leisure opportunities in certain districts, the interviewees' amount of daily-life travel was to a large extent influenced by the distance from the dwelling to the city center and a second-order center.

All the previously mentioned studies highlight the fact that people do not necessarily use the closest facilities. The implications of this to the relationships between residential location and travel are elaborated on in the studies by Næss and Jensen in the Copenhagen metropolitan area and the small town of Frederikshavn and its surroundings (Næss \& Jensen 2002, 2004, and 2005; Næss 2005, 2006a).

Among both the Copenhagen and the Frederikshavn interviewees, "distance decay" in the form of reduced activity participation when living far away from relevant facilities was not very pronounced. For workforce participation, there was hardly any tendency at all among the interviewees (nor among the survey respondents) toward reduced participation when living far away from employment concentrations, and hardly any tendency among suburbanites of more frequent home-based "teleworking" than among their inner-city counterparts. There was still a tendency among suburban women of confining their choices on the labor market to a smaller geographical area than that of their male counterparts. The modest occurrence of "distance decay" implies that long distances to workplaces and other facilities only to a very limited extent results in reduced employment or participation in leisure activities.

The interviewees' choices of locations for their activities (work, shopping, leisure, etc.) were based on a balancing between a wish to minimize traveling distances and/or travel time, and a wish for choosing the best and most suitable facility. What is considered the best facility not only involves a judgment of where the instrumental purpose of the activities can best be met, but also how well the facilities match one's cultural, aesthetic, and symbolic preferences; how suitable they are as meeting points for social contacts; or the preferred location may alternate simply for the sake of variety.

A high emphasis on minimizing the friction of distance means that less-than-ideal facilities are accepted if facilities of the desired quality are not available within a low threshold for acceptable traveling distance. On the other hand, a high emphasis on choosing the best facility means that relatively long traveling distances are accepted if necessary to access a facility of the sought-for quality. Circumstances contributing to a high priority attached to the rationale of choosing the best facility, compared to distance minimizing, include specialized 
job skills, specialized leisure interests and "exclusive" cultural taste, high availability of time, high mobility resources, availability of many facilities in the local area of the dwelling, and short distance from the local facilities to the closest competing concentration of facilities.

For most travel purposes, the Copenhagen metropolitan area interviewees valued having the option to choose among facilities rather than proximity. This means that their amount of travel was influenced to a higher extent by the location of the residence in relation to concentrations of facilities, rather than the distance to the closest single facility within a category ${ }^{4}$. In particular, this was the case for workplaces and places of higher education, but also for cultural and entertainment facilities, specialized stores and, to some extent, grocery stores. As a result, when combined with the actual spatial configuration of workplaces and service and leisure facilities, the amount of travel was particularly influenced by the location of the dwelling relative to the main center of the metropolitan area, and only to a lesser extent by its location relative to lower-order centers. For leisure activities, the "atmosphere" and the aesthetic qualities at the destination also played a role, contributing to strengthen the attraction of the central parts of the city.

The interviewees' choices of travel modes were influenced by two main groups of rationales concerning, respectively, the efficiency of the movement from origin to destination, and the process of moving from origin to destination. The first of these two groups includes concerns related to the time consumption, economic costs, and accessibility benefits of traveling by different modes. The second group includes concerns related to physically, psychologically, and socially positive or negative aspects associated with travelling by a particular mode. Several of the rationales were hinted at indirectly through a criterion of trip distance as an important condition through which more basic rationales such as time saving or limitation of physical efforts influence modal choices. Since long trips will be very time-consuming as well as physically exhausting if they are made by nonmotorized modes (in particular, by foot), rationales of time saving and limitation of physical efforts logically imply that travel modes depend on trip distances. Living close to relevant trip destinations thus contributes not only to shorter traveling distances, but also implies a higher propensity of using nonmotorized modes. For similar reasons, walking distance to public transport stops influences people's propensity to use these modes.

The emphasis attached by the interviewees on the mode

4 In the small town of Frederikshavn, the number of workplaces outside the city center and its closest surroundings was quite limited, and the option of choosing a local facility was simply not available in some of the suburbs and satellite settlements. choice rationales appears to be influenced by a number of individual and contextual conditions, including the interviewees' mobility resources, social obligations, time-geographical constraints, and the purpose of the trip.

The rationales identified for route choice in the Copenhagen study imply that the interviewees are not apt to make long detours from the shortest route to daily-life destinations. These rationales thus support, in line with the so-called activity-based approach to transport research (Jones 1990), the assumption that daily-life travel is mainly an activity derived from the need or wish to carry out other, stationary activities.

\section{$6 \quad$ Neighborhood-scale density}

Internationally, most studies of relationships between urban density and travel have focused on the neighborhood scale (e.g., Handy \& Clifton 2001; Chatman 2005; Rajamani et al. 2003; Handy et al. 2005; Boarnet \& Crane 2001). For example, the density component of "the three D's" (density, design, and diversity) coined by Cervero and Knockelman (1997) as key urban form characteristics influencing travel referred mainly_implicitly or explicitly — to the local urban neighborhood or district. In the Nordic countries, local-scale density has not been at the center of interest to the same extent, but local-area density has still been included in several studies together with variables indicating the location of dwellings, jobs, or stores (Table 2).

In a study of residential areas in Oslo, Næss, Larsen \& Røe (1995) found an influence of high local-area density in terms of a higher proportion of travel by public transport. Local-area density did not, however, show any effect on overall traveling distances. In the Copenhagen metropolitan area, Næss (2011) found a slight tendency of increased traveling distance by car for those living in a low-density local area, yet no identifiable effect was found on either modal split or overall travel distance. In another study in Greater Oslo, no effect of local-area density was found (Holden \& Norland 2004). The same applies to a study in the small Danish town of Frederikshavn (Næess \& Jensen 2004). It should be noted that in all these studies, clear correlations were found between local-area density and most travel behavior variables when controlling only for demographic and socioeconomic variables but not for the location of the dwelling relative to the city center. Once the latter variable was included in the analysis, the effects of local-area density vanished or were substantially weakened.

In a comparison of six workplaces in Greater Oslo, Næss \& Sandberg (1996) found a clear effect of local-area density on the modal split of journeys to work, with lower shares of 
Table 2: Nordic studies investigating the influence of neighborhood-scale density on travel behavior.

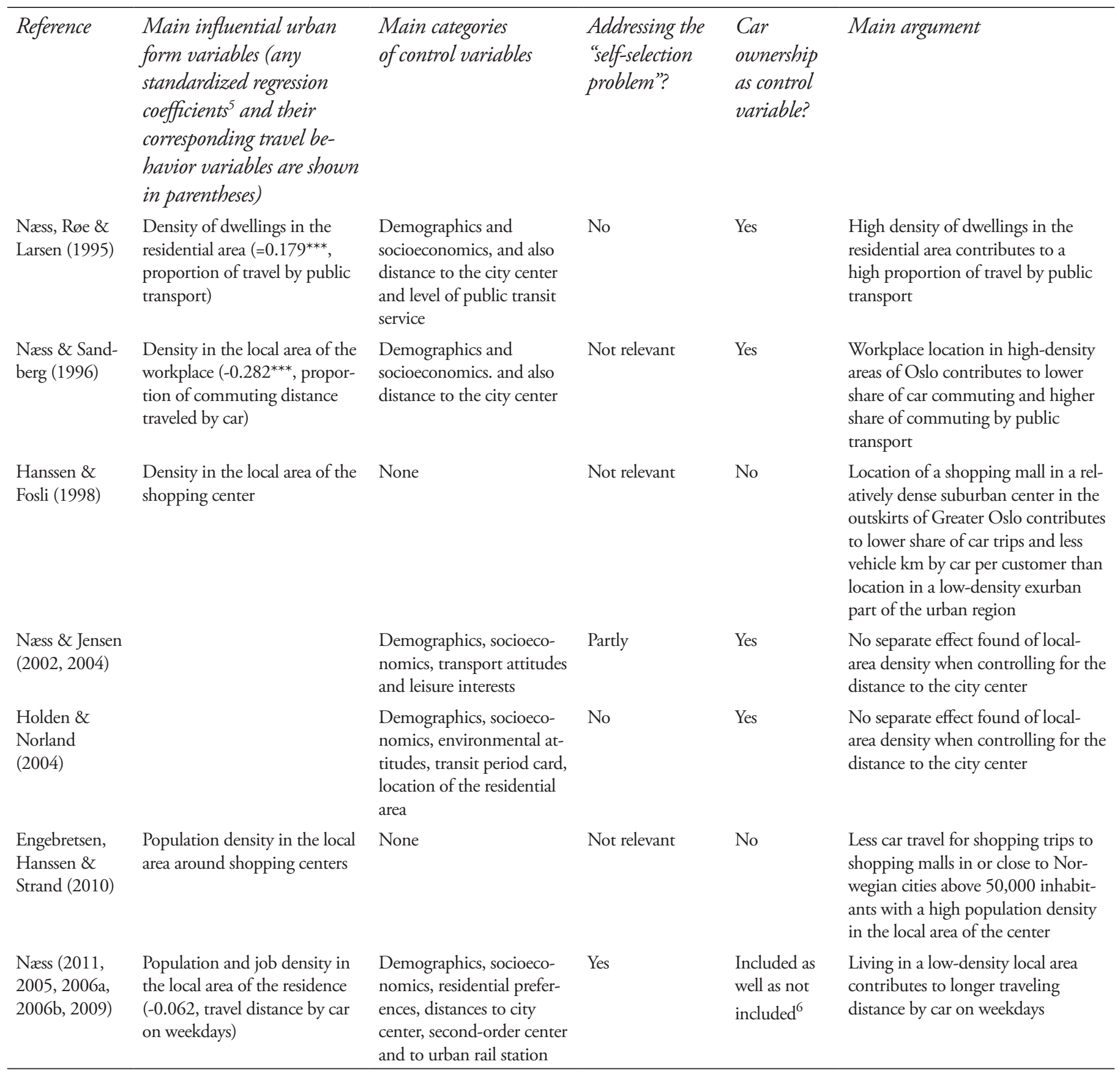

5 Levels of significance are indicated by asterisks: $<0.05=* ;<0.01=* * ;<0.001=* * *$.

6 The coefficient shown refers to an analysis not including car ownership as a control variable. 
car commuting and higher shares of travel by transit among employees of workplaces located in high-density areas. This effect persisted when controlling for the location of the workplace relative to the city center. The population density in the areas around shopping malls has also been found to influence the amount of car travel for shopping trips, measured in vehicle kilometers, as well as in the modal split between car and other modes (Hansen \& Fosli 1998; Engebretsen, Hanssen \& Strand 2010). This mainly reflects very high levels of car driving to exurban shopping malls.

The relatively modest influences of the density of residential neighborhoods found in the above-mentioned studies squares well with the findings in Ewing and Cervero's (2010) international meta-analysis, in which only small elasticities were found between vehicle miles traveled and population densities. Compared to Ewing and Cervero's meta-analysis, the Nordic studies do, however, show stronger effects of the density in the local areas around workplaces and stores.

\section{$7 \quad$ Local street pattern}

Compared to a considerable focus on neighborhood-scale street patterns in American studies, the impact of street design on travel modes or distances has been addressed in only a few Nordic studies (Table 3). In one of these studies, the relationship between the local-level street structure on traveling distance by car disappeared when controlling for the location of the residence relative to the metropolitan center (Næss 2011). In another study, Westford (2010) found a somewhat lower propensity for children who lived in a single-family home area with a grid street pattern and mixed traffic to walk to school, and a corresponding tendency of more frequent chauffeuring by car, than in three adjacent neighborhoods with separate roads for motorized and nonmotorized traffic. This tendency toward higher shares of car travel in neighborhoods with a gridshaped street pattern is the opposite of what has been concluded in several American studies.

Table 3: Nordic studies investigating the influence of neighborhood-scale street pattern on travel behavior.

\begin{tabular}{|c|c|c|c|c|c|}
\hline Reference & $\begin{array}{l}\text { Main influential urban } \\
\text { form variables (any } \\
\text { standardized regression } \\
\text { coefficients and their } \\
\text { corresponding travel } \\
\text { behavior variables are } \\
\text { shown in parentheses) }\end{array}$ & $\begin{array}{l}\text { Main categories of } \\
\text { control variables }\end{array}$ & $\begin{array}{l}\text { Addressing } \\
\text { the "self- } \\
\text { selection } \\
\text { problem"? }\end{array}$ & $\begin{array}{l}\text { Car } \\
\text { owner- } \\
\text { ship as } \\
\text { control } \\
\text { variable? }\end{array}$ & Main argument \\
\hline $\begin{array}{l}\text { Westford } \\
(2010)\end{array}$ & $\begin{array}{l}\text { Local street pattern (***, } \\
\text { traveling by foot to school) }\end{array}$ & $\begin{array}{l}\text { Demographics, socio- } \\
\text { economics }\end{array}$ & No & No & $\begin{array}{l}\text { Lower propensity for children to walk to school in a } \\
\text { single-family home area with grid street pattern and } \\
\text { mixed traffic than in three adjacent neighborhoods } \\
\text { with separate roads for motorized and nonmotorized } \\
\text { traffic }\end{array}$ \\
\hline Næss (2011) & $\begin{array}{l}\text { Local street pattern } \\
(-0.004, \text { travel distance by } \\
\text { car on weekdays })\end{array}$ & $\begin{array}{l}\text { Demographics, socio- } \\
\text { economics, residential } \\
\text { preferences, distance } \\
\text { to city center }\end{array}$ & Yes & No & $\begin{array}{l}\text { No effect found of local street pattern (grid structure } \\
\text { or other street pattern) on travel behavior variables } \\
\text { when controlling for distance to the city center } \\
\text { and demographic, socioeconomic, and attitudinal } \\
\text { variables }\end{array}$ \\
\hline
\end{tabular}

\section{Residential location at a city/metropolitan scale}

The aspect of urban form that has attracted the most research on its impacts of travel behavior in the Nordic countries is the location of residential areas. In this section attention will be directed toward the location of dwellings at a city/metropolitan scale in relation to the city center and other major concentrations of employment and regional service. This aspect has been addressed in 18 of the 30 Nordic studies included in the review (Table 4).

7 See note 5 .
Investigations in a number of Nordic cities and metropolitan areas have shown that those living in the outer parts travel considerably longer by motorized means of transportation, compared to the residents of inner and central parts of the town. The same main pattern has been found in Greater Copenhagen (Hartoft-Nielsen 2001a; Næss 2006a and b, 2009, 2011), Greater Oslo (Næss, Røe \& Larsen 1995; Røe 2001), Helsinki (Martamo 1995), Aarhus (Hartoft-Nielsen ibid.), Bergen (Duun, 1994), Trondheim (Synnes 1990), Gävle and its surroundings (Tillberg 2001), four medium-sized Danish provincial cities (Hartoft-Nielsen ibid.), and Frederikshavn 
(Næss \& Jensen 2002 and 2004). In some of these studies, the influences of residential location on trips with different purposes have been analyzed separately. A large proportion of the differential between suburbanites and inner-city dwellers in traveling distances has been found to be attributable to differences in commuting distances (Hartoft-Nielsen 2001a; Næss, 2006c, 2007b, and 2009b). However, residential location close to the concentration of facilities in the inner city has also been found to contribute to shorter non-work trips (Næss 2006c).

In his studies in the Copenhagen metropolitan area, Næss (2006a, 2011) found the impacts of metropolitan-scale urban structural variables, in particular the distance from the dwelling to the city center, to be considerably more influential than neighborhood-scale characteristics. The distance from the residence to the closest second- and third-order centers were, however, found to influence travel distances and modal shares to some extent. In Aalborg, Nielsen (2002) found the distance to the city center to be the main urban form variable influencing traveling distances, but proximity to a second-order center at the southern fringe of the city also contributed to some reduction in the distance traveled. Similar results have also been found in Greater Oslo, where, apart from the effect of living close to the city center, proximity to service facilities contributed to a certain decrease in weekly traveling distances (Næss, Røe, \& Larsen 1995; Røe 2001; Holden \& Norland 2004).

As mentioned in section 3, self-selection of residents into geographical locations matching their traveling preferences has been mentioned as a source of error precluding researchers from drawing firm conclusions about influences of residential location on travel. In 2009, the "self-selection problem" was thus the subject of a special issue of the journal Transport Reviews. In one of the articles of this special issue, Næss (2009a) takes a different view on the issues of self-selection than conventionally construed in the literature. According to Nrss, the fact that people to some extent "self-select" into areas matching their transport attitudes (and car ownership) is in itself a demonstration of the importance of urban structure to travel behavior. If there were no such influence, people who prefer to travel by nonmotorized modes might as well settle in the peripheral part of the metropolitan area, far away from public transport stops and the concentration of workplaces and service facilities found in the central and inner city. However, empirical evidence from the Copenhagen metropolitan area shows a considerable influence of residential location (in particular, the distance from the dwelling to downtown) on traveling distances by car also after controlling for residential self-selection. (Næss 2009a).

Many studies of residential location and travel-in the Nordic countries as well as internationally_include car ownership as a control variable, and some also control for attitudes to car travel. However, car ownership and transport attitudes are themselves subject to influence from residential location; by providing oneself with a car (or possibly a second car), long distances to trip destinations can be compensated through higher travel speeds, and more time will be available for other everyday activities (Hägerstrand 1970). If the purpose of the analysis is to identify and estimate the magnitude of the influence of residential location on travel, the inclusion of control variables that are related to the location of the dwelling with two-way causality leads to an underestimation of the effect of residential location (unless the indirect effects of residential location via these variables are simultaneously taken into consideration). As demonstrated by Næss (2009b), the influence of residential location on car ownership among Copenhagen metropoli$\tan$ area respondents was considerable and probably at least as strong as the influence of car ownership on residential location. Information from qualitative interviews with persons who had moved from one residential address to another address within the metropolitan area underpinned this statistical relationship. Moreover, questionnaire survey analyses of movers showed a tendency toward somewhat increased car ownership as a result of moving to a more peripheral part of the Copenhagen metropolitan area. Outer-area respondents also felt much more dependent on car travel to reach daily destinations than their inner-city counterparts (ibid.). Qualitative interviews carried out by Nielsen (2002) in Aalborg and by Røe (2002) in Oslo also illustrate the mechanisms through which moving from an inner-city to a suburban housing estate may induce people to acquire a (second) car. Clear effects of residential location on car ownership were also found in a study of the little Danish town of Frederikshavn (Næss \& Jensen 2002 and 2004).

Similarly, attitudes about car travel can influence residential location but may also be influenced by the location of the dwelling. In much of the literature on self-selection, the latter influence has been ignored. However, inner-city residents traveling mainly by public or nonmotorized modes while being exposed to nuisances from traffic originating mostly in the suburbs are likely to develop less car-friendly attitudes than suburbanites who regard the car as a necessity in order to reach their daily activities (Næss 2009a) — a point also emphasized by Bagley \& Mokhtarian (2002).

Given the (at least) equally strong effects that were found of residential location on car ownership and attitudes as in the opposite direction, Næss (2009a) recommended that only socioeconomic and demographic variables and transport-related residential preferences should be included as control variables, while car ownership and attitudes to car travel should both be excluded. Based on such a set of control variables, he found weekday traveling distances by car among residents of the most 
peripheral parts of the Copenhagen metropolitan area to average nearly four times as long as among residents living close to the city center. A very similar center-periphery gradient was also found in a previous study of the Copenhagen metropolitan area, including only income as a control variable (HartoftNielsen 2001a).

Table 4: Nordic studies investigating the influence of residential location at a city/metropolitan scale on travel behavior.

\begin{tabular}{|c|c|c|c|c|c|}
\hline Reference & $\begin{array}{l}\text { Main influential urban } \\
\text { form variables (any } \\
\text { standardized regression } \\
\text { coefficients }{ }^{8} \text { and their } \\
\text { corresponding travel be- }_{\text {havior variables are shown }} \\
\text { in parentheses) }\end{array}$ & $\begin{array}{l}\text { Main categories of } \\
\text { control variables }\end{array}$ & $\begin{array}{l}\text { Addressing } \\
\text { the "self- } \\
\text { selection } \\
\text { problem"? }\end{array}$ & $\begin{array}{l}\text { Car } \\
\text { owner- } \\
\text { ship as } \\
\text { control } \\
\text { variable? }\end{array}$ & Main argument \\
\hline Synnes (1990) & Distance to city center & None & No & No & $\begin{array}{l}\text { Longer commuting distances and total traveling } \\
\text { distance among persons living far away from the } \\
\text { city center of Trondheim }\end{array}$ \\
\hline Duun (1994) & Distance to city center & $\begin{array}{l}\text { Some control for } \\
\text { income, otherwise } \\
\text { none }\end{array}$ & No & No & $\begin{array}{l}\text { Longer mean traveling distance among households } \\
\text { living far away from the city center of Bergen }\end{array}$ \\
\hline Lahti (1995) & Distance to city center & None & No & No & $\begin{array}{l}\text { Longer mean commuting distances among } \\
\text { workforce participants living far away from the city } \\
\text { center of Helsinki }\end{array}$ \\
\hline $\begin{array}{l}\text { Næss, Røe \& } \\
\text { Larsen (1995) }\end{array}$ & $\begin{array}{l}\text { Distance to city center } \\
\left(0.472^{* * *}, \text { motorized travel }\right. \\
\text { distance }) \\
\text { Mean distance to local service } \\
\text { facilities }\left(0.158^{* *}, \text { motorized }\right. \\
\text { travel distance })\end{array}$ & $\begin{array}{l}\text { Demographics and } \\
\text { socioeconomics, and } \\
\text { also local area density } \\
\text { and level of public } \\
\text { transit service }\end{array}$ & No & Yes & $\begin{array}{l}\text { Longer weekly motorized traveling distances (and } \\
\text { also higher energy use) among residents living far } \\
\text { away from the city center of Oslo; } \\
\text { also somewhat longer motorized traveling distances } \\
\text { the further away the dwelling is located from local } \\
\text { service facilities }\end{array}$ \\
\hline $\begin{array}{l}\text { Martamo } \\
(1995)\end{array}$ & Distance to the city center & No & Not relevant & No & $\begin{array}{l}\text { Inhabitants of the outer parts of Helsinki metro- } \\
\text { politan area and the other largest Finnish urban } \\
\text { regions have longer commuting distances than } \\
\text { inhabitants of areas closer to the city centers. }\end{array}$ \\
\hline $\begin{array}{l}\text { Næss, Sand- } \\
\text { berg \& Røe } \\
\text { (1996) }\end{array}$ & $\begin{array}{l}\text { The degree of concentration of } \\
\text { the urban population toward } \\
\text { the city center }\left(0.363^{*} \text {, energy }\right. \\
\text { use for transport })\end{array}$ & $\begin{array}{l}\text { Population size, } \\
\text { composition of trades, } \\
\text { income, other socio- } \\
\text { economics, exurban } \\
\text { commuting, and } \\
\text { overall population } \\
\text { density }\end{array}$ & Not relevant & Yes & $\begin{array}{l}\text { For towns with similar population size and overall } \\
\text { population density, energy use for transportation } \\
\text { tends to be lower the shorter the average distance } \\
\text { from dwellings to downtown. }\end{array}$ \\
\hline $\begin{array}{l}\text { Hjorthol } \\
\text { 2000a) }\end{array}$ & $\begin{array}{l}\text { The part of the region in } \\
\text { which the dwelling is located } \\
(* * * \text {, commuting distance })\end{array}$ & $\begin{array}{l}\text { Demographics and } \\
\text { socioeconomics }\end{array}$ & No & Yes & $\begin{array}{l}\text { Longer commuting distances among residents of } \\
\text { the outer parts of the Oslo region than in the inner } \\
\text { city of Oslo }\end{array}$ \\
\hline $\begin{array}{l}\text { Hjorthol } \\
\text { 2000b) }\end{array}$ & $\begin{array}{l}\text { The part of the region in } \\
\text { which the dwelling is located } \\
(* * *, \text { share of car trips) }\end{array}$ & $\begin{array}{l}\text { Demographics and } \\
\text { socioeconomics }\end{array}$ & No & Yes & $\begin{array}{l}\text { Higher share of car trips among residents of the } \\
\text { outer parts of the Oslo region than in the inner city } \\
\text { of Oslo }\end{array}$ \\
\hline Tillberg (2001) & $\begin{array}{l}\text { The part of the municipality in } \\
\text { which the dwelling is located }\end{array}$ & None & No & No & $\begin{array}{l}\text { Longer weekly total traveling distances and travel } \\
\text { distances by car among residents of outer parts } \\
\text { of Gävle than among inner-city residents, and by } \\
\text { residents of a rural village than in a small peripheral } \\
\text { urban settlement }\end{array}$ \\
\hline $\begin{array}{l}\text { Hansen } \& \\
\text { Masud (2001) }\end{array}$ & Distance to the city center & Not relevant & No & No & $\begin{array}{l}\text { For daily-life routine trips, families with children } \\
\text { in the outer parts of the municipality of Randers } \\
\text { tend to travel longer distances, especially by car, } \\
\text { than their inner-city counterparts. For non-routine } \\
\text { leisure trips, no clear difference is found. }\end{array}$ \\
\hline
\end{tabular}


Hartoft

(2001a)

Distance to the city center ${ }^{* * *}$ Separate bivariate

No analyses for responvariables on weekdays) dent groups according to income, gender, driver's license holding and car ownership

Røe (2001)

Nielsen (2002) Distance to city center

Næss \& Jensen Distance to city center $(2002,2004) \quad\left(0.240^{* * *}\right.$, weekly traveling

Engebretsen (2005)

Holden \& Norland (2004)

Næss (2005,

2006a, 2006b, $\quad\left(0.145^{* * *}\right.$, total travel distance

2009 and

2011)

Distance to closest second-

Engebretsen, Hanssen \& Strand (2010)
Distance to city center $\left(0.254^{* *}\right.$, daily traveling distance)

Distance to private service facilities $(0.170$, daily traveling distance)* $\left(0.202^{* * *}\right.$, weekly traveling distance)

Distance to second-order suburban center $\left(0.097^{* * *}\right.$, weekly traveling distance) distance)

Distance to city center $\left(0.213^{* *}\right.$, energy use for everyday transport)

Distance to closest local center (0.100*,

energy use for everyday transport)

Distance to city center

on weekdays) order center $(0.055$, total travel distance on weekdays) Distance to closest urban rail station (0.046, total travel distance on weekdays)

Demographics and socioeconomics. But also controlling for commuting distance, which is hardly relevant.

Demographics and socioeconomics, plus leisure interests and place of adolescence

Demographics, socioeconomics, transport attitudes and leisure interests

None

No

Demographics, No socioeconomics, environmental attitudes, transit period card, local area density

Demographics, socio- $\quad$ Yes economics, transport attitudes, environmental attitudes, residential preferences, local area density

None (Modal split for shopping trips)
Yes

Living far away from the main city center of Copenhagen is associated with longer overall traveling distances as well as by car, shorter traveling distances by nonmotorized modes, longer commuting distances, higher share of car travel, and lower nonmotorized share. Living peripherally is also associated with somewhat longer weekend travel. Similar effects are seen in the Danish provincial city of Aarhus and (albeit weaker) in the four mediumsized provincial cities.

Yes Longer traveling distances, more frequent car trips, and less frequent nonmotorized trips among residents of outer suburbs than in Oslo's inner city. Living far away from city center and, to some extent, private service, contributes to longer overall travel distances.

Included $^{9} \quad$ Longer total traveling distances, as well as by car as well and by public transport, among residents living far as not away from the main city center of Aalborg as well included as from the suburban second-order center. Residential location also influences car ownership.

Partly Yes Living close to the city center of Frederikshavn contributes to shorter overall traveling distances, higher share of nonmotorized travel and lower share of travel by car. Residential location also influences car ownership.

No

Overall weekly traveling distance as well as the proportion traveled by car increases with increasing distance from the dwelling to the city centers of Oslo, Bergen, and Trondheim, respectively

Higher energy use for everyday transport the further away the respondents live from the main city center of Oslo, and to some extent also the further they live from the closest local center

Included $^{10}$ Living far away from the main city center of as well as not included Copenhagen contributes to longer overall traveling distances as well as by car and by public transport, shorter traveling distances by nonmotorized modes, longer commuting distances, higher shares of car travel, and lower nonmotorized share. Living peripherally also contributes to somewhat longer weekend travel. Residential location also influences car ownership.

Higher share of nonmotorized shopping trips among those residents of Norwegian cities above 50,000 inhabitants who live close to the centers of their respective cities

9 See note 6

10 See note 6. 
In Ewing \& Cervero's (2010) meta-analysis, average elasticities for associations between built environmental characteristics and aspects of travel behavior found in the various studies were calculated as the ratio of the percentage change in one variable associated with the percentage change in another variable. In the present review, strengths of relationships have been indicated (where available) by standardized regression coefficients, but we have not calculated averages across studies. Since the relationships between residential location and travel are not necessarily linear (this depends, among others, on how widely the investigated area has been demarcated), elasticities for relationships between residential location and travel may be different in different parts of a city or metropolitan area. Generally, the change in a travel behavior variable resulting from a given change in the distance to the city center will be smaller if the distance to the city center is at the outset long than if the first location is in the inner parts of the city. Moreover, the change in traveling distance resulting from a one- $\mathrm{km}$ increase in the distance between the city center and the dwelling is smaller in big cities than in small towns, where built environment characteristics may change from inner-city to rural over a few kilometers. On the other hand, the total differential between center and periphery in traveling distances tends to be larger in larger cities than in smaller cities, since the centers of the former are attracting labor and visitors from a larger hinterland (cf. Christaller, 1933/1966). In a Danish context, Hartoft-Nielsen (2001a) thus found traveling distances by car among residents on the metropolitan fringe to be on average four times as long as among inner-city dwellers in the Copenhagen region (population: approx. 1.8 million, of which 1.2 million are in the continuous urban area), three times as long in Aarhus (population: approx. 300,000, of which 240,000 are in the continuous urban area), and two and a half times as long in four smaller provincial towns (population ranging from 32,000 to 55,000).

Based on experience from four comparable Nordic studies (method-wise), Figure 1 shows how the average daily traveling distance by motorized modes of travel has been found to vary with the distance from the dwelling to the city center. In the figure, the effects of residential location have been controlled for socioeconomic and demographic variables (and in the metropolitan area of Copenhagen also for transport-related residential preferences), but not for car ownership or attitudes to car travel.



Figure 1: Relationships between residential location and traveling distance by motorized modes found in four urban regions. Sources: Nielsen, 2002, pp. 238 and 260 (Aalborg); and data files from studies published in Næss, 2009b (Copenhagen metropolitan area); Næss, Røe \& Larsen, 1995 (Greater Oslo); and Næss \& Jensen, 2004 (Frederikshavn) ${ }^{11}$

\section{$9 \quad$ Location of workplaces and retail at a city/metropolitan scale}

Compared to the large body of literature on residential location and travel, considerably fewer Nordic studies have addressed the impacts of workplace location on travel behavior (Table 5). Common to these studies is, however, the finding that lower proportions of the employees commute by car and higher proportions travel by public transit, bicycle, or by foot to workplaces located in the inner city than to suburban job sites (Monsen 1983; Hanssen 1993; Martamo 1995; Næss \& Sandberg 1996; Hartoft-Nielsen 2001b; Strømmen 2001; Næss 2007b). In particular, a strong center-periphery gradient has been found for office workplaces. In a study of 52 offices in the Copenhagen metropolitan area, Hartoft Nielsen (2001b) found that the proportion of employees commuting by car tended to increase from $40-45$ percent at downtown workplaces to 80 percent when the distance between the workplace and downtown was $30 \mathrm{~km}$. In addition, a clear effect of proximity to urban rail stations could be seen. Among the in-

11 Copenhagen metropolitan area has around 1.8 million inhabitants, of which 1.2 million are within the continuous urban area (stretching some 20$30 \mathrm{~km}$ out from the city center, and with a population density of 32 persons per hectare). Oslo metropolitan area has approximately 1.2 million inhabitants, of which 0.9 million are within the continuous urban area (stretching some 7-30 km out from the city center, and with a population density of 31 persons per hectare). Aalborg and its nearest suburbs have around 160,000 inhabitants, of which 120,000 are within the continuous urban area (stretching some 4-7 km out from the city center, and with a population density of 24 persons per hectare). Frederikshavn and its nearest suburbs have approximately 35,000 inhabitants, of which 25,000 in the continuous urban area (stretching some $2-3.5 \mathrm{~km}$ out from the city center, and with a population density of 19 persons per hectare). 
ner-city workplaces located closest to main urban rail stations, the proportions of car commuters were only 10 to 25 percent. In the outer areas, proximity to a junction urban rail station typically reduced the proportion of car commuters from 75-85 percent to 40-60 percent. Similar differences between center and periphery have been found in Helsinki in Finland (Martamo 1995) and in Oslo and Trondheim in Norway (Monsen 1983; Næss \& Sandberg 1996; Strømmen 2001). In Oslo, a clear separate effect of the level of public transit services and parking availability at the workplace has been demonstrated in a study of workplaces relocating to a new site at similar distances from the city center as the old locations (Tennøy \& Lowry 2008). In Danish provincial cities, a center-periphery gradient for the modal split has also been found, yet with a smaller difference between city center and suburb in the share of car commuters than in the Copenhagen metropolitan area (HartoftNielsen 2001b; Møller \& Næss 2000).

Some planners have believed that the higher proportion of car trips to suburban jobs would be compensated for by shorter commuting distances, since suburban workplaces might recruit a high proportion of their employees from nearby residential neighborhoods. However, in the Nordic studies, there is little evidence of any such overall tendency. For office workplaces, average commuting trips instead appear to increase slightly the more peripherally the jobs are located (Hartoft-Nielsen 2001b; Strømmen 2001). While office workplaces are often highly specialized, less specialized workplaces (e.g., retail, primary education, kindergartens, and health care) may be able to recruit employees locally more often. Among residents of the Copenhagen metropolitan area with an education level below the median, commuting distances thus tend to increase the closer the workplace is located to the city center, whereas an opposite tendency can be seen among those with education above the median. In total, for all types of workplaces, the longest mean commuting distances were found among employees located some $10-25 \mathrm{~km}$ from the city center, with shorter journeys to work among those working more centrally as well as those working in the outermost parts of the Copenhagen metropolitan area (Næss 2007b). This pattern cannot, however, be taken as a general rule. In Helsinki, Martamo (1995) has found a nearly opposite pattern, with the longest commutes to centrally located jobs and to jobs in outer-suburban employment centers at the main roads, and shorter journeys among employees of workplaces in the inner suburbs. Yet, similar to Copenhagen, commuting distances tended to drop when the distance from the job site to the city center of Helsinki increased beyond some $20-25 \mathrm{~km}$.

In the Copenhagen metropolitan area, the differences in commuting distances among different educational groups also translate into corresponding differences between employees with high and low educational levels in the ways in which workplace location affects modal split. The proportion of car commuters among respondents with a low level of education was thus lowest, and the proportion of walk/bike commuters highest, at workplaces located between 15 and $28 \mathrm{~km}$ from downtown Copenhagen. Among respondents with a high level of education, the lowest share of car commuters and the highest share of nonmotorized commuting were found at workplaces located less than $6 \mathrm{~km}$ from downtown (Næss 2007b), similar to the distribution found in Hartoft-Nielsen's (2001b) study of employees at office workplaces.

For several categories of businesses, the trips generated by visitors are dominant, compared to the employees' journeys to work. This applies to, for example, shops, schools, and other types of public and private service. The Nordic studies of transport impacts of the location of service facilities have concentrated on the location of shopping malls (Table 6). In all these studies (two Norwegian and one Swedish), the out-of-town location of shopping malls has been found to contribute to higher shares of car trips and more vehicle kilometers by car (Svensson 1998; Hanssen \& Fosli 1998; Engebretsen et al. 2010). According to the former of these studies, the distance traveled by car for shopping in Linköping, Sweden, increased by 50 percent owing to the establishment of three out-of-town shopping malls.

\section{Population density at a city scale}

Inspired by Newman \& Kenworthy's (1989) study of urban density and gasoline consumption in 32 cities worldwide, investigations into the relationships between city-scale urban density and energy use for transportation in Nordic cities were carried out in the first half of the 1990s (Table 7). When discussing the influence of travel from population density at a citywide scale, it is important that the area within which density is demarcated is measured in an appropriate way. The relevant area is the urbanized land (including built-up areas, and infrastructure as well as parks and other smaller intra-urban open areas). Such demarcations were used in the Nordic studies as well as in Newman \& Kenworthy's earlier investigation. In the most comprehensive of the Nordic studies, 22 cities in Norway, Denmark, Sweden, and Iceland were investigated, with energy data based on fuel sales and electricity use for public transit services. In line with theoretical expectations (cf. section 2), a clear relationship between urban population density and energy use for transport was found (Næss, Sandberg \& Røe 1996), still present when controlling for a number of other urban form and socio-economic variables (including population size and 
Table 5: Nordic studies investigating the influence of workplace location at a city/metropolitan scale on travel behavior.

\begin{tabular}{|c|c|c|c|c|c|}
\hline Reference & $\begin{array}{l}\text { Main influential urban } \\
\text { form variables (any } \\
\text { standardized regression } \\
\text { coefficients }{ }^{12} \text { and their } \\
\text { corresponding travel } \\
\text { behavior variables are } \\
\text { shown in parentheses) }\end{array}$ & $\begin{array}{l}\text { Main categories of } \\
\text { control variables }\end{array}$ & $\begin{array}{l}\text { Addressing } \\
\text { the "self- } \\
\text { selection } \\
\text { problem"? }\end{array}$ & $\begin{array}{l}\text { Car } \\
\text { owner- } \\
\text { ship as } \\
\text { control } \\
\text { variable? }\end{array}$ & Main argument \\
\hline $\begin{array}{l}\text { Monsen } \\
(1983)\end{array}$ & Distance to the city center & None & Not relevant & No & $\begin{array}{l}\text { Relocation of workplaces from inner districts to the } \\
\text { outskirts of Greater Oslo has resulted in increased } \\
\text { shares of car travel and somewhat longer commuting } \\
\text { distances. }\end{array}$ \\
\hline $\begin{array}{l}\text { Hanssen } \\
(1993)\end{array}$ & Distance to the city center & None & Not relevant & No & $\begin{array}{l}\text { Relocation of branches of an insurance company } \\
\text { from inner districts of Oslo to a common site at a } \\
\text { suburban local center has resulted in increased shares } \\
\text { of car travel. }\end{array}$ \\
\hline $\begin{array}{l}\text { Martamo } \\
(1995)\end{array}$ & Distance to the city center & No & Not relevant & No & $\begin{array}{l}\text { Employees of workplaces located in the central parts } \\
\text { of the Helsinki metropolitan area have longer com- } \\
\text { muting distances than employees working in the in- } \\
\text { ner suburbs. Employees of outer-suburban employ- } \\
\text { ment centers along the main roads have commuting } \\
\text { distances similar to inner-city employees. Patterns are } \\
\text { less clear in the other Finnish urban regions. }\end{array}$ \\
\hline $\begin{array}{l}\text { Næss \& Sand- } \\
\text { berg (1996) }\end{array}$ & $\begin{array}{l}\text { Distance to the city center } \\
\left(0.252^{* * *}, \text { proportion of }\right. \\
\text { commuting distance traveled } \\
\text { by car })\end{array}$ & $\begin{array}{l}\text { Demographics and } \\
\text { socioeconomics }\end{array}$ & Not relevant & Yes & $\begin{array}{l}\text { Workplace location close to the city center of Oslo } \\
\text { contributes to lower share of car commuting, higher } \\
\text { share of commuting by public transport, and lower } \\
\text { energy use for commuting. }\end{array}$ \\
\hline $\begin{array}{l}\text { Møller \& Næss } \\
(2000)\end{array}$ & $\begin{array}{l}\text { Distance to city center***, } \\
\text { likelihood of commuting } \\
\text { by car }\end{array}$ & $\begin{array}{l}\text { A few socioeconomic } \\
\text { variables }\end{array}$ & Not relevant & No & $\begin{array}{l}\text { Higher likelihood of commuting by car if the } \\
\text { workplace is located far away from the city center of } \\
\text { Aalborg }\end{array}$ \\
\hline $\begin{array}{l}\text { Hartoft- } \\
\text { Nielsen } \\
\text { (2001b) }\end{array}$ & $\begin{array}{l}\text { Distance to city center } \\
\left(0.59^{* * *} \text { for Copenhagen }\right. \\
\text { metropolitan area, propor- } \\
\text { tion of commuting trips by } \\
\text { car })\end{array}$ & None & Not relevant & No & $\begin{array}{l}\text { Higher proportion of commuting trips by car, lower } \\
\text { proportion of commutes by transit, longer traveling } \\
\text { distances by car, and longer overall traveling distances } \\
\text { among employees of office workplaces located far } \\
\text { away from the city center of Copenhagen. Similar, } \\
\text { but weaker, effects in the Danish provincial cities of } \\
\text { Aarhus, Odense, Aalborg, and Vejle. }\end{array}$ \\
\hline $\begin{array}{l}\text { Strømmen } \\
(2001)\end{array}$ & $\begin{array}{l}\text { Location according to the } \\
\text { Dutch } A B C \text { criteria }\end{array}$ & $\begin{array}{l}\text { Demographic and } \\
\text { socioeconomic }\end{array}$ & Not relevant & No & $\begin{array}{l}\text { Lower proportion of car commuting and higher } \\
\text { proportion of commuting by public transport to } \\
\text { workplaces located in A-areas (close to the city center } \\
\text { of Trondheim, where accessibility by public transit is } \\
\text { high and availability of parking is low). }\end{array}$ \\
\hline $\begin{array}{l}\text { Tennøy \& } \\
\text { Lowry (2008) }\end{array}$ & $\begin{array}{l}\text { Parking availability and } \\
\text { public transit accessibility }\end{array}$ & No & Not relevant & No & $\begin{array}{l}\text { Reduced proportions of car commuting among } \\
\text { employees of four research institutes in Oslo relocat- } \\
\text { ing to a site with higher accessibility by public transit } \\
\text { and lower parking availability. (Average distance to } \\
\text { city center remained almost the same.) }\end{array}$ \\
\hline
\end{tabular}

12 See note 5 . 
Table 6: Nordic studies investigating the influence of the location of shopping malls at a city/metropolitan scale on travel behavior.



13 See note 5.

Table 7: Nordic studies investigating the influence of population density at a city scale on energy use for transportation.

\begin{tabular}{|c|c|c|c|c|c|}
\hline Reference & $\begin{array}{l}\text { Main influential } \\
\text { urban form variables (any } \\
\text { standardized regression } \\
\text { coefficients }{ }^{14} \text { and their cor- } \\
\text { responding travel behavior } \\
\text { variables are shown in } \\
\text { parentheses) }\end{array}$ & $\begin{array}{l}\text { Main categories of } \\
\text { control variables }\end{array}$ & $\begin{array}{l}\text { Addressing } \\
\text { the "self- } \\
\text { selection } \\
\text { problem"? }\end{array}$ & $\begin{array}{l}\text { Car } \\
\text { owner- } \\
\text { ship as } \\
\text { control } \\
\text { variable? }\end{array}$ & Main argument \\
\hline $\begin{array}{l}\text { Næss } \\
(1993)\end{array}$ & $\begin{array}{l}\text { Population density within } \\
\text { demarcations of continuous } \\
\text { urbanized land }\left(0.70^{* * *} \text {, energy }\right. \\
\text { use for transport })\end{array}$ & $\begin{array}{l}\text { Population size, income } \\
\text { level, and proportions living } \\
\text { in the main town of the mu- } \\
\text { nicipality and in rural areas }\end{array}$ & Not relevant & No & $\begin{array}{l}\text { Among Swedish municipalities including } \\
\text { a town of at least } 10,000 \text { inhabitants, high } \\
\text { mean population density within the demar- } \\
\text { cations of the urbanized areas contributes to } \\
\text { lower energy use for transportation. }\end{array}$ \\
\hline $\begin{array}{l}\text { Næss, Sand- } \\
\text { berg \& Røe } \\
\text { (1996) }\end{array}$ & $\begin{array}{l}\text { Population density within } \\
\text { demarcations of continuous } \\
\text { urbanized land }\left(0.370^{* * *} \text {, }\right. \\
\text { energy use for transport) }\end{array}$ & $\begin{array}{l}\text { Population size, composi- } \\
\text { tion of trades, income, other } \\
\text { socioeconomics, exurban } \\
\text { commuting, and degree of } \\
\text { concentration of the urban } \\
\text { population toward the city } \\
\text { center }\end{array}$ & Not relevant & Yes & $\begin{array}{l}\text { Among } 22 \text { Nordic cities, high population } \\
\text { density within the demarcations of the } \\
\text { urbanized areas contributes to lower energy } \\
\text { use for transportation. }\end{array}$ \\
\hline
\end{tabular}

14 See note 5 . 
income level). A similar study of 97 Swedish cities also clearly showed higher levels of energy use for transport in low-density than in high-density cities, also after controlling for other key factors of influence (Næss 1993).

\section{Centralization vs. decentralization at a regional scale}

At shown in section 8, at the level of individual cities or metropolitan areas there is strong evidence that residential locations close to downtown contribute to reducing the amount of travel in general, and travel by car in particular. Some professionals maintain that this will also be the case at the level of larger regions (for instance, a county or a province), from a line of argument that there will be a lot of crisscrossing transport between the different local communities in regions with a decentralized population pattern. However, evidence from the Nordic countries (Table 8) suggests that centralization at a wider regional scale may not entail the same benefits as centralization within a metropolitan area or a city, seen from a perspective of reducing energy use and emissions from transport.

In the study of the Copenhagen metropolitan area mentioned earlier (cf. section 8), a slight tendency of reduced travel distances could be observed among residents of the most peripheral parts, i.e., more than $45 \mathrm{~km}$ away from the city center (Næss 2006a). In a study of three Danish provinces, Næss \& Johannsen (2003) found that the amount of motorized travel tended to increase at a steady pace with increasing distance from home to the center of the closest main town, up to a distance of some 15 to 25 kilometers. Beyond that distance, traveling distances began to decline again, reaching levels in the most peripheral locations only slightly above the levels found among the residents living closest to the center of one of the county's main towns.

A study of commuting distances in Finnish municipalities points in the same direction. Here, people living in rural and peripheral municipalities were found to usually have shorter commuting distances than those living in the suburbs of the largest cities (Martamo 1995). Similarly, an investigation of transport energy use in Swedish regions found that energy use tended to increase the more the regional population was concentrated around the largest town of the region. Contrary to expectations, a high degree of urbanization-meaning that the proportion of the regional population living in rural areas and small settlements is small - tended to increase the use of energy for transport. On the other hand, a high population density within the cities contributed (as might be expected) to reduced energy use. (Næss 1993).
The above-mentioned studies of traveling distances at the regional or provincial level clearly point at "distance decay" in the attractiveness of a large center. Beyond the range of influence of the largest centers, most people are likely to orient themselves to a greater extent to smaller, more local centers, even if the job opportunities and selection of service facilities are narrower than in the big city.

\section{Discussion}

The Nordic studies reviewed in this paper provide evidence that several urban form characteristics influence the inhabitants' amount of transport and their choice of means of conveyance. The rationales for location of activities, choice of transport modes, and route choice identified in qualitative research make up important links in the mechanisms by which urban structures influence travel behavior. Notably, the tendency of inhabitants of modern cities to emphasize (within some threshold distances) the possibility of choosing among facilities rather than proximity means that the amount of travel is influenced to a higher extent by the location of the residence in relation to concentrations of facilities, rather than the distance to the closest single facility within a category. Daily traveling distances, therefore, tend to be more influenced by the distance from the dwelling to the city's main concentration of facilities (usually the inner city) than by its distance to local centers. The transport rationales identified in the Nordic studies are hardly unique to the Scandinavian context. In a subsequent study of residential location and travel in Hangzhou, China, very similar transport rationales as those of the Copenhagen interviewees have been found (Næss 2009b and 2013, forthcoming). This similarity across widely differing contexts suggests that there may be a high degree of generality of the basic mechanisms through which urban form influences travel behavior.

The conclusions from the Nordic studies add to the quite overwhelming international evidence that urban spatial structures matter to travel behavior and are in line with what could be expected from theoretical insights within fields such as transportation geography (Tobler 1970; Jones 1978; Fox 1995), time-geography (Hägerstrand 1970), and central place theory (Christaller 1933/1966; Berry \& Garrison 1958). However, whereas much of the research in the United States and parts of Europe has focused on the influences of local neighborhood characteristics on travel, the Nordic research shows the effects on travel behavior mainly from urban form characteristics at a higher geographical scale: the overall population density within continuous urban areas, and the locations of residences and workplaces relative to the city-level or met- 
Table 8: Nordic studies investigating the influence of centralization vs. decentralization at a regional scale on travel behavior and energy use for transportation.

\begin{tabular}{|c|c|c|c|c|c|}
\hline Reference & $\begin{array}{l}\text { Main influential urban } \\
\text { form variables (any } \\
\text { standardized regression } \\
\text { coefficients }{ }^{15} \text { and their } \\
\text { corresponding travel } \\
\text { behavior variables are } \\
\text { shown in parentheses) }\end{array}$ & $\begin{array}{l}\text { Main categories of } \\
\text { control variables }\end{array}$ & $\begin{array}{l}\text { Addressing } \\
\text { the "self- } \\
\text { selection } \\
\text { problem"? }\end{array}$ & $\begin{array}{l}\text { Car } \\
\text { owner- } \\
\text { ship as } \\
\text { control } \\
\text { variable? }\end{array}$ & Main argument \\
\hline $\begin{array}{l}\text { Larsen et al. } \\
\text { (1982) }\end{array}$ & $\begin{array}{l}\text { Location of the dwellings } \\
\text { relative to centers at different } \\
\text { levels in a center hierarchy }\end{array}$ & $\begin{array}{l}\text { Unclear, but probably } \\
\text { none }\end{array}$ & No & No & $\begin{array}{l}\text { Energy use for transport in Denmark increases as } \\
\text { distance increases from the dwelling to the closest } \\
\text { main city or town center, with the lowest energy use } \\
\text { in the centers of the largest cities. On the other hand, } \\
\text { energy use for transport is generally higher in the } \\
\text { most urbanized regions of the country. }\end{array}$ \\
\hline Næss (1993) & $\begin{array}{l}\text { Degree of concentration of } \\
\text { the regional population to } \\
\text { the biggest city } \\
\left(-0.60^{*} \text {, energy use for }\right. \\
\text { transport })\end{array}$ & $\begin{array}{l}\text { Population den- } \\
\text { sity within cities and } \\
\text { urban settlements, } \\
\text { income level }\end{array}$ & No & No & $\begin{array}{l}\text { At the regional level, decentralized concentration- } \\
\text { i.e., a settlement structure where a moderate part of } \\
\text { the regional population is concentrated in the biggest } \\
\text { town, while each town and settlement has a high } \\
\text { population density—appears to be the most energy- } \\
\text { efficient pattern. }\end{array}$ \\
\hline $\begin{array}{l}\text { Martamo } \\
(1995)\end{array}$ & $\begin{array}{l}\text { Distance from dwelling } \\
\text { to the center of the closest } \\
\text { larger city }\end{array}$ & None & No & No & $\begin{array}{l}\text { Commuting distances in Finland tend to increase as } \\
\text { distance increases from home to the closest main city } \\
\text { center, up to a "turning point" beyond which further } \\
\text { increase of the distance to the city center contributes } \\
\text { to reduce the mean commuting distances. These } \\
\text { "turning points" are further away from the city } \\
\text { centers the larger the city is. In the most remote rural } \\
\text { regions, commuting distances are on average short. }\end{array}$ \\
\hline $\begin{array}{l}\text { Næss \& } \\
\text { Johannsen } \\
(2003)\end{array}$ & $\begin{array}{l}\text { Distance from dwelling } \\
\text { to the center of the closest } \\
\text { larger town }\left(0.115^{*} \text { - }\right. \\
0.163^{* * *} \text {, weekly motorized } \\
\text { travel distance) }\end{array}$ & $\begin{array}{l}\text { Income, age, house- } \\
\text { hold composition and } \\
\text { size, vehicle owner- } \\
\text { ship }\end{array}$ & No & $\begin{array}{l}\text { In- } \\
\text { cluded }^{16} \\
\text { as well } \\
\text { as not } \\
\text { included }\end{array}$ & $\begin{array}{l}\text { Increasing distance from the dwelling to the center } \\
\text { of the closest larger town in the counties of North } \\
\text { Jutland, Ringkjøbing, and Vejle up to } 15-20 \mathrm{~km} \\
\text { contributes to an increase in the amount of motor- } \\
\text { ized travel, but when the distance to the center of the } \\
\text { closest town increases beyond this level, the amount } \\
\text { of motorized travel tends to decrease. }\end{array}$ \\
\hline Næss (2006a) & $\begin{array}{l}\text { Distance from dwelling to } \\
\text { the main metropolitan city } \\
\text { center }\end{array}$ & $\begin{array}{l}\text { Demographics, socio- } \\
\text { economics, } \\
\text { transport attitudes, } \\
\text { environmental at- } \\
\text { titudes, residential } \\
\text { preferences, local area } \\
\text { density }\end{array}$ & Partly & $\begin{array}{l}\text { Included } \\
\text { as well } \\
\text { as not } \\
\text { included }\end{array}$ & $\begin{array}{l}\text { When the distance from the dwelling to the city } \\
\text { center of Copenhagen exceeds } 40-45 \mathrm{~km} \text {, mean } \\
\text { traveling distances decrease slightly. }\end{array}$ \\
\hline
\end{tabular}

15 See note 5.

16 See note 6 . 
ropolitan center structure. These relationships also exist when taking into account self-selection based on transport-related residential preferences and when controlling for car ownership. Many inner-city residents walk, cycle, or go by public transport to their daily destinations even if they have a car at their disposal, and this reduced car usage is only to a small extent, if at all, compensated through weekend driving. This illustrates the point made by Kaufmann (2002) that the potential for movement (motility, according to Kaufmann's vocabulary) is not automatically realized as actual movement (observable travel). However, as shown in some of the Nordic studies, car ownership is itself influenced by residential location, and including car ownership as a control variable may therefore be inappropriate. Although many studies - internationally as well as in the Nordic countries-have treated car ownership as an exogenous control variable and thus ignored the influence of residential location on car ownership, the two-way influence characterizing this relationship is increasingly being acknowledged in the international research (Giuliano \& Narrayan 2003; Scheiner \& Holz-Rau 2007, Vance \& Hedel 2008; Zegras 2010; Aditjandra et al. 2010).

Similar strong influences of residential location relative to the city center on traveling distances (in total or by car) as those found in the Nordic studies have also been identified in a number of other cities around the world, including Paris (Mogridge 1985; Fouchier 1998); London (Mogridge ibid.); New York and Melbourne (Newman and Kenworthy 1989); San Francisco (Schipper et al. 1994); Austin, Texas (Zhou \& Kockelman 2008); Athens (Milakis, Vlastos and Barbopoulos); Hangzhou (Næss 2009b and 2010), and Santiago de Chile (Zegras 2010). These cities are all more or less monocentric. In cities with a more polycentric structure, the influence of the distance to the city center itself may be weaker. For example, in a study of Greater Oporto, Portugal, most travel behavior variables were found to be more closely related to local-area density than the distance to the main city center ${ }^{17}$ (Næss, Silva $\&$ Pinho n.d.).

The influences of workplace location on commuting patterns found in the Nordic studies also resemble the relationships found in a number of international studies. Cities for which lower proportions of car commuters and higher proportions of employees traveling by public transit, bicycle, or foot have been found at inner-city than at suburban job sites include the San Fransisco Bay area (Cervero \& Landis 1992); London and other large British cities (Dasgupta 1994); the Dutch Randstadt area (Schwanen et al. 2001); Atlanta and Boston (Yang 2005); and Paris (Aguilera et al. 2009). Several

17 The distance to the main city center still influences travel behavior indirectly, since local-area densities tend to be higher in the inner than in the outer parts of Greater Oporto. studies of cities in other parts of the world also support the conclusion from the Nordic studies that job decentralization from inner to outer parts of cities and metropolitan areas usually does not contribute to reducing average commuting distances (Cervero \& Landis 1992; Yang 2005; Aguilera et al. 2009). Admittedly, according to some studies, employment decentralization has reduced commuting times (Gordon et al. 1991; Cervero \& Landis 1992; Giuliano \& Small 1993). This is, however, mostly because of the generally higher shares of fast modes of travel and higher driving speeds in the suburbs than in the inner city.

The influence of the population density for the city as a whole on energy use for transportation found in the Nordic studies squares well with the results of Newman \& Kenworthy's (1989) much-cited study, as well as earlier studies such as Keyes's (1976) comparison of fuel consumption in 49 American metropolitan areas in the 1970s, and more recent analyses including an expansion of Newman \& Kenworthy's sample to 84 cities (Kenworthy 2003; Lefevre 2010). The Nordic finding that local-area density shows much weaker relationships with travel behavior is also in line with international experience. For example, in Ewing and Cervero's (2010) meta-analysis, only small elasticities were found between vehicle miles traveled and, respectively, population and job densities. Moreover, in many of the international studies where the impact of localarea density has been assessed, no control has been made for the location of the neighborhood relative to the city center (e.g. van Acker et al. 2007). This should, however, not lead us to conclude that a high local-area density contributes only marginally to reducing car traffic and emissions from transport. Local-area densities add up to the overall density of the city, and a high neighborhood-scale density strengthens the population base for local service facilities and thus increases the likelihood that such destinations can be found within walking distance.

Interestingly, none of the Nordic studies appear to have investigated the influence of degree of mixed land uses in the local neighborhood (the Diversity component of "the three D's" emphasized by Cervero and Knockelman 1997). This omission may—at least partly—be based on an implicit assumption that people living in a neighborhood will neither necessarily be employed at the workplaces in the same neighborhood (i.e., that the local jobs-housing balance may not be very important) nor primarily use the local shopping and leisure facilities, cf. the transport rationales discussed in section 5. Studies of other European cities (e.g., Milakis et al. 2008) suggest that the local jobs-housing balance may exert some influence on mean trip lengths by car as well as the share of public transport (for the latter, probably because jobs in a residential neighborhood in- 
crease the population base for a higher level of public transport services).

The Nordic studies addressing possible influences of neighborhood-scale street pattern and travel behavior have either found no such relationship whatsoever, or relationships opposite to those found in American studies (e.g., Cervero 2003; Frank 2003). This gives rise to a suspicion that the relationships between street pattern and travel found in some American studies might perhaps reflect the location of the residential areas rather than the shape of the local street network. In Ewing and Cervero's (2010) meta-analysis, street intersection density and street connectivity were found to be almost as influential as distance to downtown or employment concentrations on the number of vehicle kilometers traveled. However, based on the transport rationales discussed in section 5 , it is difficult to justify why local-area street design would exert any strong influence on overall traveling distances by car. Instead, the location of the residence relative to main concentrations of facilities (in particular, employment) could be expected to exert far stronger influence on traveling distances in general and car travel in particular.

The Nordic studies suggest that while at an intra-metropolitan scale a centralized pattern of development will require the least amount of energy for transportation, decentralized concentration may be the most energy-efficient settlement pattern at a wider regional scale. According to Brotchie (1984), a decentralized settlement structure will be the most energy efficient and least transport-requiring one if the level of physical mobility in the society is low. In such a situation, the distance decay will be high, with rationales of minimizing distance outweighing those of choosing the best facility. In a highly mobile society, however, the deterrent of distance will be low, with rationales of choosing the best facility generally dominating over distance minimization (within some threshold of acceptable travel time). If a peripheral settlement is to function in a selfcontained way in a high-mobility society, it must be located outside the catchment area of competing centers. Thus, Banister (1992) found that traveling distances were shortest and the proportion of walking highest in the most urbanized of six investigated parishes in generally densely populated Southern England, while the most rural parish was distinguished by long trips and a high proportion of car driving. If residential development in peripheral rural areas and villages in a high-mobility society is to be compatible with modest average amounts of travel, the distances to the closest cities (and in particular, major metropolitan centers) must therefore most likely be quite long (Breheny 1992).

\section{Acknowledgements}

The author wants to thank Andrés Felipe Valderrama Pineda and the two anonymous referees of JTLU for valuable comments on previous versions of the paper.

\section{References}

Aditjandra, P., X. Cao, and C. Mulley. 2010. Understanding neighbourhood design impact on travel behaviour: An application of structural equations model to the British micro-analysis data. Presented at the 12th World Congress on Transport Research in Lisbon, Portugal, July 11-15, 2010.

Aguiléra, A., S. Wenglenski, and L. Proulhac. 2009. Employment suburbanisation, reverse commuting and travel behaviour by residents of the central city in the Paris metropolitan area. Transportation Research A, 43(7): 685-691. doi: 10.1016/j.tra.2009.06.004.

Banister, D. 1992. Energy use, transport and settlement patterns. In M. Breheny, ed., Sustainable Development and Urban Form, 160-181. London: Pion Limited.

Beckmann, J. 2001. Risky mobility: The filtering of automobility's unintended consequences. Ph.D. thesis, University of Copenhagen, Department of Sociology.

Bhaskar, R. 1998. The Possibility of Naturalism: A Philosophical Critique of the Contemporary Human Sciences, 3rd ed. London and New York: Routledge.

Boarnet, M. G. and R. Crane. 2001. Travel by Design. Oxford: Oxford University Press.

Breheny, M. 1995. The compact city and transport energy consumption. Transactions of the Institute of British Geographers, 20: 81-101. URL http://www.jstor.org/stable/622726.

Brotchie, J. F. 1984. Technological change and urban form. Environment and Planning A, 16: 583-596. doi: 10.1068/ a160583.

Bruegmann, R. 2005. Sprawl: A Compact History. Chicago: University of Chicago Press.

Cao, X., P. L. Mokhtarian, and S. Handy. 2009. Examining the impacts of residential self-selection on travel behaviour: A focus on empirical findings. Transport Reviews, 29: 359395. doi: 10.1080/01441640802539195.

Cervero, R. and K. Kockelman. 1997. Travel demand and the 3Ds: Density, diversity, and design. Transportation Research D, 2(3): 199-219. doi: 10.1016/S1361-9209(97)00009-6.

Cervero, R. and J. Landis. 1992. Suburbanization of jobs and the journey to work: A submarket analysis of commuting in the San Francisco Bay Area. Journal of Advanced Transportation, 26: 275-297. doi: 10.1002/atr.5670260305. 
Chatman, D. G. 2005. How the built environment influences non-work travel: Theoretical and empirical essays. Ph.D. thesis, University of California, Los Angeles. URL http://policy.rutgers.edu/faculty/chatman/Howenvironmenttravel. pdf.

Christaller, W. 1966. Central Places in Southern Germany. Englewood Cliffs, NJ: Prentice-Hall. Translation of Die Zentralen Orte in Süddeutschland, published in 1933.

Crane, R. 1996. On form versus function: Will the new urbanism reduce traffic, or increase it? Journal of Planning Education and Research, 15(2): 117-126. doi: 10.1177/0739456X9601500204.

Dasgupta, M. 1994. Urban travel demand and policy impacts. Presented at the course "Byens miljø- og trafikkpolitikk" at Norwegian Institute of Technology, Trondheim, January 10-12, 1994.

Duun, H. P. 1994. The Transportation Effects of Urban Development: A Study of Transportation Effects, Energy Use and Emission to the Air from Different Urban Development Strategies in Bergen (Byutviklingens transportvirkninger. En studie av transporteffekter, energibruk og utslipp til luft ved alternative byutviklingsstrategier i Bergen). Bergen: West Norwegian Planning Group.

Engebretsen, Ø. 2005. Location and daily mobility. Presented at the 45th Congress of the European Regional Science Association at Vrije Universiteit, Amsterdam, August 23-27, 2005.

Engebretsen, Ø., J. U. Hanssen, and A. Strand. 2010. Retail Location and Transportation (Handelslokalisering og transport). Oslo: Institute of Transport Economics.

Ewing, R. and R. Cervero. 2001. Travel and the built environment: A synthesis. Transportation Research Record, 1780: 87-114. URL http://depts.washington.edu/trac/concurrency/lit_review/trr1780.pdf.

Ewing, R. and R. Cervero. 2010. Travel and the built environment. Journal of the American Planning Association, 76: 1-30. doi: 10.1080/01944361003766766.

Ewing, R., R. C. Brownson, and D. Berrigan. 2006. Relationship between urban sprawl and weight of United States youth. American Journal of Preventive Medicine, 31: 464 474. doi: 10.1016/j.amepre.2006.08.020.

Fouchier, V. 1998. Urban density and mobility in Ile-de France Region. Presented at the UN-ECE 8th conference on Urban and Regional Research, Madrid, June 8-11, 1998.

Frank, L. and G. Pivo. 1994. Relationships between land use and travel behavior in the Puget Sound region. Technical report, Washington State Transportation Center. URL http:// www.wsdot.wa.gov/research/reports/fullreports/351.1.pdf.

Frank, L. D., M. A. Andresen, and T. L. Schmid. 2004. Obe- sity relationships with community design, physical activity, and time spent in cars. American Journal of Preventive Medicine, 27(2): 87-96. doi: 10.1016/j.amepre.2004.04.011.

Giuliano, G. and K. A. Small. 1993. Is the journey to work explained by urban structure? Urban Studies, 30(9): 14851500. doi: 10.1080/00420989320081461.

Giuliano, G. and D. Narayan. 2003. Another look at travel patterns and urban form: The US and Great Britain. Urban Studies, 40(11): 2295-2312. doi: 10.1080/0042098032000123303.

Gordon, I. 1997. Densities, urban form and travel behaviour. Town \& Country Planning, 66: 239-241.

Gordon, P. and H. W. Richardson. 1997. Are compact cities a desirable planning goal? Journal of the American Planning Association, 63: 95-105. doi: 10.1080/01944369708975727.

Gordon, P., H. W. Richardson, and M.-J. Jun. 1991. The commuting paradox: Evidence from the top twenty. Journal of the American Planning Association, 57: 416-420. doi: 10.1080/01944369108975516.

Hägerstrand, T. 1970. What about people in regional science? Papers of the Regional Science Association, 24: 7-21. doi: 10.1007/BF01936872.

Handy, S. L. and K. L. Clifton. 2001. Local shopping as a strategy for reducing automobile travel. Transportation, 28(4): 317-346. doi 10.1023/A:1011850618753.

Handy, S., X. Cao, and P. Mokhtarian. 2005. Correlation or causality between the built environment and travel behavior? Evidence from Northern California. Transportation Research Part D, 10: 427-444. doi: 10.1016/j. trd.2005.05.002.

Hanssen, J. U. 1993. Transport Consequences of the Location of Businesses (Transportmessige virkning er av næringsvirksomheters lokalisering). Oslo: Institute of Transport Economics.

Hanssen, J. U. and O. Fosli. 1998. Shopping Centers: Location and Use (Kjøpesentre - lokalisering og bruk). Oslo: Institute of Transport Economics.

Hartoft-Nielsen, P. 2001a. Residential Location and Travel Behavior (Boliglokalisering og transportadfærd). Hørsholm: Danish Forest and Landscape Research Institute.

Hartoft-Nielsen, P. 2001b. Workplace Location and Travel Behavior (Arbejdspladslokalisering og transportadfærd). Hørsholm: Forskningscenteret for skov og landskab.

Headicar, P. 2003. The contribution of land use planning to reducing traffic growth: The English experience. European Journal of Transport Infrastructure Research, 2: 137154. URL http://www.ejtir.tudelft.nl/issues/2003_02/ pdf/2003_02_02.pdf.

Hjorthol, R. J. 2000a. Same city—different options. An analy- 
sis of the work trips of married couples in the metropolitan area of Oslo. Journal of Transport Geography, 8: 213-220. doi: 10.1016/S0966-6923(99)00040-X.

Hjorthol, R. J. 2000b. Reurbanisation and its potential for the reduction of car use. An analysis of preferences of residence, activity and travel pattern in the Oslo area. Housing, Theory and Society, 17: 211-226. doi: 10.1080/02815739808730458.

Holden, E. and I. T. Norland. 2004. A Study of Households' Consumption of Energy in the Dwellings and for Heaing in Greater Oslo (En undersøkelse av husholdningers forbruk av energi til bolig og transport i Stor-Oslo). Oslo: University of Oslo.

Holden, E. 2007. Achieving sustainable mobility. Everyday and leisure-time travel in the EU. Aldershot, UK and Burlington, USA: Ashgate.

Jones, P. 1978. Destination choice and travel attributes. In D. Hensher and Q. Dalvi, eds., Determinants of Travel Choice, pp. 266-311. England: Saxon House.

Kaufmann, V. 2002. Re-Thinking Mobility: Contemporary Sociology. Aldershot: Ashgate.

Kenworthy, J. R. 2003. Transport energy use and greenhouse gases in urban passenger transport systems: A study of 84 global cities. Presented to the international Third Conference of the Regional Government Network for Sustainable Development, Notre Dame University, Fremantle, Western Australia, September 17-19, 2003. URL http://cst.uwinnipeg.ca/documents/Transport_Greenhouse.pdf.

Keyes, D. L. 1976. Energy and land use: An instrument of US conservation policy? Energy Policy, 4: 225-236. doi: 10.1016/0301-4215(76)90040-9.

Kitamura, R., P. L. Mokhtarian, and L. Laidet. 1997. A microanalysis of land use and travel in five neighborhoods in the San Francisco Bay Area. Transportation, 24: 125-158. doi: 10.1023/A:1017959825565.

Krizek, K. J. 2003. Residential relocation and changes in urban travel: Does neighborhood-scale urban form matter? Journal of American Planning Association, 69: 265-281. doi: 10.1080/01944360308978019.

Larsen, F. 1982. Passenger Transport and Its Energy Consumption in Different Center Types (Persontrafikken og dens energiforbrug i forskellige centertyper). Copenhagen: The Planning Directorate and the Ministry of Public Works.

Lefévre, B. 2010. Urban transport energy consumption: determinants and strategies for ts reduction. Sapiens, 2: 1-17. URL http://sapiens.revues.org/index914.html

Litman, T. 2009. Generated traffic and induced travel: Implications for transport planning. Victoria: Victoria Transport Policy Institute. URL http://www.vtpi.org/gentraf.pdf.
Martamo, R. 1995. Distance between Workplace and Residence in Finland (Työssäkäyntietäisyydet Suomessa). Miljöministeriet, Markanvändingsavdelningen.

Masud, P. and R. Hansen. 2001. Transport, Urban Structure and Lifestyle (Transport, bystruktur og livsstil). Aalborg University, Department of Development and Planning.

Milakis, D., T. Vlastos, and N. Barbopoulos. 2008. Relationships between urban form and travel behaviour in Athens, Greece: A comparison with Western European and North American results. European Journal of Transport Infrastructure Research, 8: 201-215. URL http://www.ejtir.tbm. tudelft.nl/issues/2008_03/abstracts/2008_03_02.asp.

Mogridge, M. J. H. 1985. Transport, land use and energy interaction. Urban Studies, 22(6): 481-492. doi: 10.1080/00420988520080851.

Mogridge, M. J. H. 1997. The self-defeating nature of urban road capacity policy: A review of theories, disputes and available evidence. Transport Policy, 4(1): 5-23. doi: 10.1016/S0967-070X(96)00030-3.

Monsen, G. 1983. Relocation of businesses: Changes in journeys to work and energy use (Bedriftsflytting - endring i arbeidsreise og energiforbruk). Cand. polit. Dissertation. Oslo: University of Oslo.

Møller, J. S. and P. Næss. 2000. Workplace location and modal choice: the case of Aalborg (Arbejdspladslokalisering og transportmiddelvalg ved bolig-arbejdsrejser - eksemplet Aalborg). Byplan, 6: 238-247.

Needham, B. 1977. How Cities Work: An Introduction. London: Pergamon Press.

Newman, P. W. G. and J. R. Kenworthy. 1989a. Cities and Automobile Dependence. Aldershot: Gower Publications.

Newman, P. W. G. and J. R. Kenworthy. 1989b. Gasoline consumption and cities: A comparison of US cities with a global survey. Journal of the American Planning Association, 55: 24-37. doi: 10.1080/01944368908975398.

Newman, P. W. G. and J. R. Kenworthy. 1999. Sustainability and Cities: Overcoming Automobile Dependence. Washington DC and Covelo, California: Island Press.

Nielsen, T. S. 2002. Residential location and transport in Aalborg (Boliglokalisering og transport i Aalborg), Ph.D. thesis, Aalborg University. URL http://en.sl.life.ku.dk/upload/ phddissertation2002.pdf.

Noland, R. B. and L. L. Lem. 2002. A review of the evidence for induced travel and changes in transportation and environmental policy in the US and the UK. Transportation Research Part D, 7(1): 1-26. doi: 10.1016/S13619209(01)00009-8.

Nowlan, D. M. and G. Stewart. 1991. Downtown population growth and commuting trips: Recent experience in 
Toronto. Journal of the American Planning Association, 57: 165-182. doi: 10.1080/01944369108975485.

Næss, P. 1993. Transportation energy in Swedish towns and regions. Scandinavian Housing \& Planning Research, 10: 187-206. doi: 10.1080/02815739308730340.

Næss, P. 2004. Prediction, regressions and critical realism. Journal of Critical Realism, 3: 133-164. doi: 10.1163/1572513041172713.

Næss, P. 2005. Residential location affects travel behaviorBut how and why? The case of Copenhagen metropolitan area. Progress in Planning, 63(2): 167-257. doi: 10.1016/j. progress.2004.07.004.

Næss, P. 2006a. Urban Structure Matters: Residential Location, Car Dependence and Travel Behaviour. New York/London: Routledge.

Næss, P. 2006b. Are short daily trips compensated by higher leisure mobility? Environment \& Planning B, 33: 197-220. doi: $10.1068 / \mathrm{b} 31151$.

Næss, P. 2006c. Accessibility, activity participation and location of activities: Exploring the links between residential location and travel behavior. Urban Studies, 43: 627-652. doi: 10.1080/00420980500534677.

Næss, P. 2007a. Residential location and travel in Hangzhou metropolitan area. NIBR report 2007:1. Oslo: Norwegian Institute for Urban and Regional Research. URL http:// www.nibr.no/publikasjoner/rapporter/3/

Næss, P. 2007b. The impacts of job and household decentralization on commuting distances and travel modes: Experiences from the Copenhagen region and other Nordic urban areas. Informationen zur Raumentwicklung, Heft 2/3.2007, 149-168. URL http://www.bbsr.bund.de/cln_016/ nn_82470/BBSR/EN/Publications/IzR/2007/Issue2_3. html.

Næss, P. 2009b. Residential location, travel behavior, and energy use: Hangzhou Metropolitan Area compared to Copenhagen. Indoor and Built Environment, 18: 382-395. doi: 10.1177/1420326X09346215.

Næss, P. 2009a. Residential self-selection and appropriate control variables in land use: Travel studies. Transport Reviews, 29: 293-324. doi: 10.1080/01441640802710812.

Næss, P. 2011. "New urbanism” or metropolitan-level centralization? A comparison of the influences of metropolitanlevel and neighborhood-level urban form characteristics on travel behavior. Journal of Transport and Land Use, 4(1): 25-44. URL https://www.jtlu.org/index.php/jtlu/article/ view/170.

Næss, P. 2013. Residential location, transport rationales and daily-life travel behavior: The case of Hangzhou Metropolitan Area, China. Forthcoming in Progress in Planning,
79(1).

Næss, P. and O. B. Jensen. 2002. Urban land use, mobility and theory of science: Exploring the potential for critical realism in empirical research. Journal of Environmental Policy and Planning, 4(4): 295-311. doi: 10.1002/jepp.114.

Nrss, P. and O. B. Jensen. 2004. Urban structure matters, even in a small town. Journal of Environmental Planning and Management, 47(1): 35-56. doi: 10.1080/0964056042000189790.

Næss, P. and O. B. Jensen. 2005. The Car Tires and the Bike Hub: Residential Location, Car Dependence and Travel Behavior in the Capital Area (Bilringene og cykelnavet. Boliglokalisering, bilafhængighed og transportadfærd i Hovedstadsområdet). Aalborg: Aalborg University Press.

Næss, P. and H. H. W. Johannsen. 2003. Urban patterns of development affect travel behaviour-Also at a regional level. Presented at the XVII Aesop Congress in Leuven, Belgium, July 8-12, 2003.

Næss, P., M. J. H. Mogridge, and S. L. Sandberg. 2001. Wider roads, more cars. Natural Resources Forum, 25(2): 147-155. doi: 10.1111/j.1477-8947.2001.tb00756.x.

Næss, P., P. G. Røe, and S. L. Larsen. 1995. Travelling distances, modal split and transportation energy in thirty residential areas in Oslo. Journal of Environmental Planning and Management, 38(3): 349-370. doi: 10.1080/09640569512913.

Næss, P. and S. L. Sandberg. 1996. Workplace location, modal split and energy use for commuting trips. Urban Studies, 33(3): 557-580. doi: 10.1080/00420989650011915.

Næss, P., S. L. Sandberg, and P. G. Røe. 1996. Energy use for transportation in 22 Nordic towns. Scandinavian Housing \& Planning Research, 13: 79-97. doi: 10.1080/02815739608730401.

Næss, P., T. Næss, and A. Strand. 2011. Oslo's farewell to urban sprawl. European Planning Studies, 19(1): 113-139. doi: 10.1080/09654313.2011.530395.

Næss, P., A. Strand, T. Næss, and M. Nicolaisen. 2011. On their road to sustainability? The challenge of sustainable mobility in urban planning and development in two Scandinavian capital regions. Town Planning Review, 82(3): 285-315. doi: 10.3828/tpr.2011.18.

Nrss, P., C. Silva, and P. Pinho. n.d. Residential location and travel in a polycentric city. Paper currently under peer review.

Nørgaard, J. S. 2008. Avoiding rebound through a steady-state economy. In H. Herring and S. Sorrell, eds., Energy Effciency and Sustainable Consumption: The Rebound Effect, pp. 204-223. Basingstoke: Palgrave Macmillan.

Owens, S. 1986. Energy, Planning and Urban Form. London: Pion Limited. 
Rajamani, J., C. R. Bhat, S. Handy, G. Knapp, and Y. Song. 2003. Assessing the impact of urban form measures in nonwork trip mode choice after controlling for demographic and level-of-service effects. Presented at the 2003 Transportation Research Board conference. URL http://www. ce.utexas.edu/prof/bhat/ABSTRACTS/FINAL_Jayanthi. pdf.

Real Estate Research Corporation. 1974. The Costs of Sprawl: Environmental and Economic Costs of Alternative Residential Development Patterns at the Urban Fringe. Washington, D. C.: U.S. Government Printing Office.

Røe, P. G. 2001. The daily-life trips of the urbanite: Relationships between place of residence, lifestyle and everyday traveling practice in a late modern perspective (Storbymenneskets hverdagsreiser. Sammenhenger mellom bosted, livsstil og hverdagsreisepraksis i et senmoderne perspektiv). Dr. Polit. dissertation. Trondheim: Norwegian University of Technology and Science.

Scheiner, J. and C. Holz-Rau. 2007. Travel mode choice: affected by objective or subjective determinants? Transportation, 34: 487-511. doi: 10.1007/s11116-007-9112-1.

Schipper, L., E. Deakin, and D. Spearling. 1994. Sustainable transportation: The future of the automobile in an environmentally constrained world. Presented at a research seminar arranged by the Board of Communications Research, Stockholm, September 23, 1994.

Schwanen, T. and P. L. Mokhtarian. 2004. The extent and determinants of dissonance between actual and preferred residential neighbourhood type. Environment \& Planning B, 31: 759-784. URL http://www.envplan.com/abstract. cgi?id=b3039.

Schwanen, T., F. M. Dieleman, and M. Diest. 2001. Travel behaviour in Dutch monocentric and policentric urban systems. Journal of Transport Geography, 9: 173-186. doi: 10.1016/S0966-6923(01)00009-6.

Stead, D. and S. Marshall. 2001. The relationships between urban form and travel patterns: An international review and evaluation. European Journal of Transport Infrastructure Research, 1(2): 113-141. URL http://www.ejtir.tudelft.nl/ issues/2001_02/pdf/2001_02_01.pdf.

Strømmen, K. 2001. Right workplace at the right location: on the transport-generating properties of workplaces (Rett virksomhet på rett sted - om virksomheters transportskapende egenskaper). Ph.D. thesis, Norwegian University of Technology and Science. URL http://ntnu.diva-portal.org/ smash/record.jsf?pid=diva2:121827.

Svensson, T. 1998. The structural transformation of retail: driving forces and ramifications to urban spatial development and the environment (Dagligvarudistributionens strukturom- vandling - Drivkrafter og konsekvenser för stadens utformning och miljö). Ph.D. thesis, University of Linköping. Synnes, H. 1990. Traveling habits in Trondheim 1990 (Reisevaner i Trondheim 1990). MSc dissertation, unpublished. Norwegian Institute of Technology.

Tennøy, A. and M. Lowry. 2008. Traveling habits among employees of the CIENS companies before and after relocation to the Research Park (Reisevaner for ansatte i CIENS-bedriftene før og etter samlokalisering i Forskningsparken). Oslo: Institute of Transport Economics.

Tillberg, K. 2001. The daily leisure trips of families with children in automobile society: A time puzzle with geographical and gender variations (Barnfamiljers dagliga fritidsresor i bilsamhället - ett tidspussel med geografiska og könsmässiga variationer). Geografiska regionstudier, 43. Uppsala: Uppsala University.

Tobler, W. 1970. A computer movie. Economic Geography, 46: 234-240. URL http://www.jstor.org/stable/143141.

Van Acker, V., F. Witlox, and B. Van Wee. 2007. The effects of the land use system on travel behavior: A structural equation modeling approach. Transportation Planning and Technology, 30: 331-353. doi: 10.1080/03081060701461675.

Vance, C. and R. Hedel. 2008. On the link between urban form and automobile use: Evidence from German survey data. Land Economics, 84: 51-65. doi: 10.3368/le.84.1.51.

Vilhelmson, B. 1990. Our daily mobility: On the development, distribution and limits of traveling (Vår dagliga rörlighet. Om resandets utveckling, fördelning och gränser). TFB-rapport 1990:16. Stockholm: Transportforskningsberedningen.

Williams, K., E. Burton, and M. Jenks. 2000. Achieving sustainable urban form: Conclusions. In K. Williams, E. Burton, and M. Jenks, eds., Achieving Sustainable Urban Form, pp. 347-355. London: Pion Limited.

Westford, P. 2010. Neighborhood design and travel: A study of residential quality, child leisure activity and trips to school. Doctoral dissertation. Stockholm: Royal Institute of Technology.

Yang, J. 2005. Commuting impacts of spatial decentralization: A comparison of Atlanta and Boston. Journal of Regional Analysis \& Policy, 35: 69-78. URL http://www.jrap-journal.org/pastvolumes/2000/v35/35-1-6.pdf.

Zegras, C. 2010. The built environment and motor vehicle ownership and use: Evidence from Santiago de Chile. Urban Studies, 47: 1793-1817.doi: 10.1177/0042098009356125.

Zhou, B. and K. Kockelman. 2008. Self-selection in home choice: Use of treatment effects in evaluating the relationship between the built environment and travel behavior. Transportation Research Record, 2077: 54-61. doi: 10.3141/2077-08. 